San Jose State University

SJSU ScholarWorks

Master's Theses

Master's Theses and Graduate Research

1994

\title{
Coverage of the 1989 Chinese democracy movement by three Chinese-language newspapers published in the United States
}

Jia Kathy Li

San Jose State University

Follow this and additional works at: https://scholarworks.sjsu.edu/etd_theses

\section{Recommended Citation}

$\mathrm{Li}$, Jia Kathy, "Coverage of the 1989 Chinese democracy movement by three Chinese-language newspapers published in the United States" (1994). Master's Theses. 929.

DOI: https://doi.org/10.31979/etd.ah5v-3tz5

https://scholarworks.sjsu.edu/etd_theses/929

This Thesis is brought to you for free and open access by the Master's Theses and Graduate Research at SJSU ScholarWorks. It has been accepted for inclusion in Master's Theses by an authorized administrator of SJSU ScholarWorks. For more information, please contact scholarworks@sjsu.edu. 


\section{INFORMATION TO USERS}

This manuscript has been reproduced from the microfilm master. UMI films the text directly from the original or copy submitted. Thus, some thesis and dissertation copies are in typewriter face, while others may be from any type of computer printer.

The quality of this reproduction is dependent upon the quality of the copy submitted. Broken or indistinct print, colored or poor quality illustrations and photographs, print bleedthrough, substandard margins, and improper alignment can adversely affect reproduction.

In the unlikely event that the author did not send UMI a complete manuscript and there are missing pages, these will be noted. Also, if unauthorized copyright material had to be removed, a note will indicate the deletion.

Oversize materials (e.g., maps, drawings, charts) are reproduced by sectioning the original, beginning at the upper left-hand corner and contimuing from left to right in equal sections with small overlaps. Each original is also photographed in one exposure and is included in reduced form at the back of the book.

Photographs included in the original manuscript have been reproduced xerographically in this copy. Higher quality $6^{\prime \prime} \times 9^{n}$ black and white photographic prints are available for any photographs or illustrations appearing in this copy for an additional charge. Contact UMI directly to order.

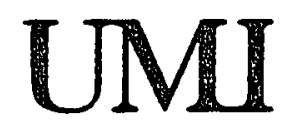

A Bell \& Howell information Company 



\title{
COVERAGE OF THE 1989 CHINESE DEMOCRACY MOVEMENT \\ BY THREE CHINESE-LANGUAGE NEWSPAPERS \\ PUBLISHED IN THE UNITED STATES
}

\author{
A Thesis \\ Presented to \\ San Jose State University \\ In Partial Fulfillment \\ of the Requirements for the Degree \\ Master of Science
}

The Faculty of the School of Journalism and Mass Communications

by

Jia Kathy Li

December 1994 
UMI Number: 1361187

Copyright 1994 by

Li, Jia Rathy

All rights reserved.

UMI Microform Edition 1361187

Copyright 1995, by UMI Company. All rights reserved.

This microform edition is protected against unauthorized copying under Title 17, United States Code.

\section{UMI}

300 North Zeeb Road

Ann Arbor, MI 48103 
(C) 1994

Jia Kathy Li

ALL RIGHTS RESERVED 
APPROVED FOR THE SCHOOL OF

JOURNALISM AND MASS COMMUNICATIONS

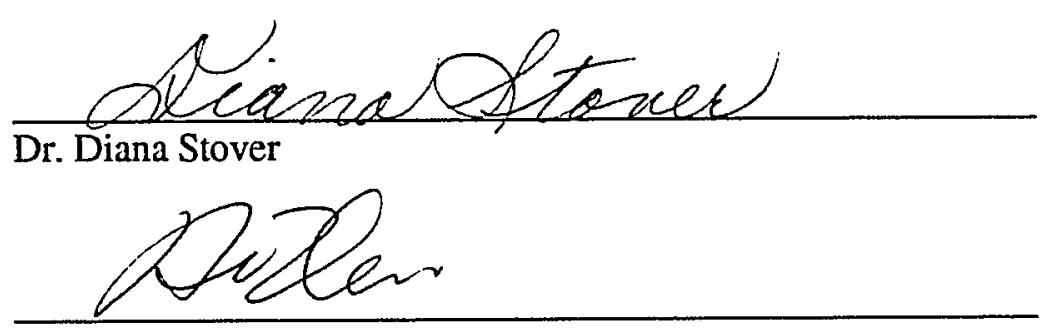

Dr. Chou He

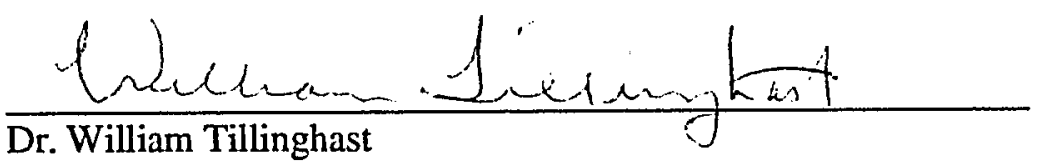

APPROVED FOR THE UNIVERSITY

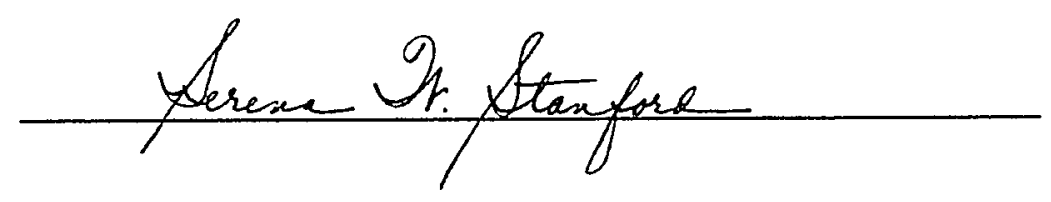




\title{
ABSTRACT \\ COVERAGE OF THE 1989 CHINESE DEMOCRACY MOVEMENT BY THREE CHINESE-LANGUAGE NEWSPAPERS PUBLISHED IN THE UNITED STATES
}

\author{
by Jia Kathy Li
}

This thesis compared the coverage of the 1989 Chinese pro-democracy movement by three Chinese-language newspapers in the United States: the World Journal from Taiwan, People's Daily from China, and Sing Tao Daily from Hong Kong. The 3,521 news items published by these daily newspapers between April 15 and June 10, 1989 were content analyzed. The study found that political differences they inherited from their homelands were reflected in the newspapers' coverage. Major findings are: (1) both Sing Tao Daily and the World Journal increased their coverage as the movement developed while the amount of coverage in the People's Daily fluctuated depending on the tightness of government control; (2) both Sing Tao Daily and the World Journal consistently covered the movement in a positive tone while half of People's Daily's coverage was negative; (3) both Sing Tao Daily and the World Joumal relied heavily on their own staff and western news agencies while People's Daily got most of its news from Xinhua News Agency; (4) the three newspapers differed significantly in explaining the movement's causes and in their coverage of key players. 
Dedicated to My Mother

A Constant Source of Inspiration in My Life 


\section{ACKNOWLEDGEMENT}

The completion of this thesis would not have been possible without the support and guidance of many individuals to whom I am truly in debt.

I would first like to thank my thesis committee. My profound gratitude goes to Dr. Diana Stover, my advisor and mentor. Her expertise in this field and her constant encouragement kept me from giving up this project. Dr. Zhou He's extensive knowledge of the Chinese media has been invaluable in helping me set up the framework for this thesis. Dr. William Tillinghast's expertise in statistics and media research assisted me a great deal in analyzing the data.

I would like to acknowledge the encouragement and assistance provided by my friends at the San Jose State University Library, especially Judy Reynolds and Jo Whitlatch. My gratitude also goes to many supporting friends, including Dave de Give and his family.

Finally, I wish to thank all my family members, especially my mother and my younger brother, for their love, support, and understanding. 


\section{TABLE OF CONTENTS}

I. INTRODUCTION .................................................................................

Chinese Language Newspapers in the United States......................................... 1

Purpose of Study.................................................................................................... 2

II. LITERATURE REVIEW .........................................................................

News and Reality......................................................................................

Political Ideologies and the Press in China, Taiwan, and Hong Kong............. 5

The press in China............................................................................... 5

The press in Taiwan............................................................................... 8

The press in Hong Kong.................................................................. 11

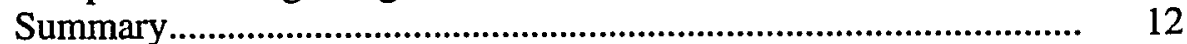

Background of the Three Chinese-language Daily Newspapers...................... 13

Background of People's Daily (from China)..................................... 14

Background of the World Journal (from Taiwan)............................. 15

Background of Sing Tao Jih Pao (from Hong Kong)........................ 16

Previous Studies of Media Coverage on

the Chinese Democracy Movement................................................... 17

Research Questions.......................................................................................... 19

III. METHODS.......................................................................................... 22

Historical and Social Context......................................................................... 22

Content Analysis........................................................................................... 23

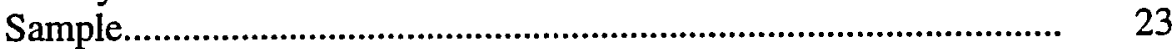

Measurement............................................................................... 24

Coding categories and operational definitions..................................... 24

Six time periods.................................................................................. 28

Intercoder reliability............................................................................. 28

IV. CHINESE DEMOCRACY MOVEMENT: AN OVERVIEW................. 30

Chronology of the Chinese Democracy Movement in 1989........................... 30

April 15-April 25, 1989.................................................................... 31

April 26-May 3, 1989....................................................................... 32

May 4-May 16, 1989...................................................................... 33

May 17-May 19, 1989...................................................................

May 20-June 2, 1989..................................................................... 34

June 3-June 10, 1989.....................................................................

May Fourth Movement.................................................................................. 36

Hong Kong's Return to China in 1997 ........................................................... 37

Taiwan's Mainland Policies............................................................................. 38

V. CONTENT ANALYSIS OF THE DIFFERENCES IN
COVERAGE OF THE DEMOCRACY MOVEMENT.......................... 40

Coverage in the World Journal ....................................................................... 40

Coverage of the Chinese democracy movement.................................. 41 
Type of coverage............................................................................. 42

Sources of news............................................................................ 44

Tone of the coverage and sources of news......................................... 46

Purpose of the movement and the sources of news........................... 46

Reaction to the movement.............................................................. 47

Causes of the movement as the event developed................................... 48

Coverage in People's Daily................................................................... 49

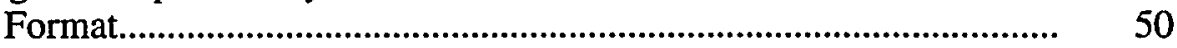

Coverage of the Chinese democracy movement................................... 51

Causes of the movement in People's Daily......................................... 52

Type of coverage and sources of news............................................ 53

Tone of the coverage and sources of news......................................... 53

Purpose of the movement and the sources of news............................ 54

Reaction to the movement................................................................... 55

Coverage in Sing Tao Jih Pao...................................................................... 55

Coverage of the Chinese democracy movement.................................. 56

Type of coverage and sources of news.............................................. 57

Tone of the coverage and sources of news........................................ 58

Purpose of the movement and sources of news.................................. 58

Reaction to the movement................................................................. 59

Causes of the movement over six time periods.................................. 60

Comparison of the World Journal, People's Daily, and Sing Tao Jih Pao..... $\quad 61$

Cross-comparison on the percentage of news hole during the six time periods................................................................. 61

Cross-comparison of coverage on key players..................................... 62

Contrast in the tone of coverage........................................................... 63

Overall comparisons of the coverage................................................... 65

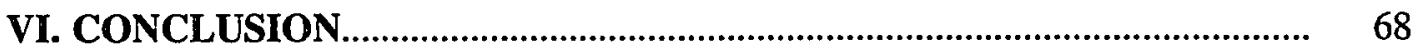

Summary of Findings................................................................................... 70

Contributions to the Literature.............................................................................

Limitations of the Study.................................................................................. 71

Directions for Future Research..........................................................................

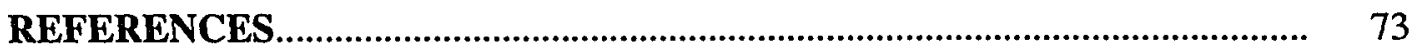




\section{LIST OF TABLES}

Table 1 Hierarchy System of the Chinese Media............................................... 7

Table 2 Type of Coverage in the World Journal .......................................... 45

Table 3 Tone of the Coverage of Sources of News in World Journal............. 46

Table 4 Reaction to the Movement by China's Government and Residents in the World Journal................................................... 47

Table $5 \quad$ Tone of the Coverage by Sources of News in People's Daily............. 54

Table 6 Type of Coverage by Sources of News in Sing Tao Daily.................. 57

Table $7 \quad$ Tone of the Coverage by Sources of News....................................... 58

$\begin{array}{ll}\text { Table } 8 & \text { Reaction to the Democracy Movement by China's } \\ \text { Government and Residents in Sing Tao Daily.................................... } & 59\end{array}$

Table 9 Comparisons of Coverage of the Chinese Democracy Movement in 1989 by the World Journal, People's Daily, and Sing Tao Daily.... 66 


\section{LIST OF FIGURES}

Figure 1 Percent of News Hole in the World Journal Devoted to the

Democracy Movement between April 15 and June 10, 1989

Figure 2 Causes of the Movement over Six Time Periods

in the World Journal.

Figure 3 Percent of News Hole in People's Daily Devoted to Coverage of the Democracy Movement between April 15 and June 10, 1989......

Figure 4 Causes of the Movement over Six Time Periods in People's Daily

Figure 5 Percent of News Hole in Sing Tao Daily Devoted to the Coverage of the Democracy Movement between April 15 and June 10, 1989.....

Figure 6 Causes of the Movement over Six Time Periods in Sing Tao Daily

Figure 7 Comparison of the Amount of Coverage by Percent of News Hole during Six Time Periods.

Figure 8 Comparison of Coverage on Key Players by the World Journal, People's Daily, and Sing Tao Daily between April 15 and June 10, 1989

Figure 9 Contrasting Tone in the Coverage of the Democracy Movement by the World Journal, People's Daily, and Sing Tao Daily. 


\section{CHAPTER I}

\section{INTRODUCTION}

In the spring of 1989 , story after story about the Chinese student demonstrations reached every nation and stunned the world. Under a Beijing dateline, stories reported moving scenes of hunger strikers fainting under the hot sun in Tiananmen Square and waves of demonstrations joined by people from all walks of life. The news media covered the expected pressure from the government, the unexpected failure of martial law and, finally, the shocking news of the Beijing Massacre.

While millions of Americans read page after page of news stories about the demonstrations in Tiananmen Square or watched as the events unfolded on their TV screens, millions of Chinese within China's borders knew little about what was going on in their capital.

For American journalists, the events in Beijing were front page news. They had the necessary elements for headline news--confrontations and dramatic change in progress--and themes in accord with the political beliefs of America: democracy and freedom of speech. Although many Chinese journalists might have agreed with their American counterparts, the Chinese government, which controls all media in mainland China, viewed the demonstrations in a negative light. In Taiwan, the press cheered for the students who dared to oppose the policies of the Communist government and, in Hong Kong, the newspapers were filled with concern and support for the Beijing demonstrators.

\section{Chinese Language Newspapers in North America}

In North America today, more than a hundred Chinese newspapers and magazines are published and circulated. A large number of these Chinese publications owe their success to capital investments and support from overseas, that is, from Hong Kong, 
Taiwan, and China. Since some of these newspapers have financial support and even direct administrative control from overseas, they often represent the interests of specific political groups. Chinese newspapers linked to Taiwan and China are still guarded towards one another although they have cut down on the use of hostile language since the normalization of Sino-American relations (Lai, 1987). During the Beijing student demonstrations in the Spring of 1989, differences in the coverage of this event by these foreign-linked Chinese newspapers were obvious. The Beijing-linked People's Daily described the student demonstrations as "riots," while the Taiwan-linked World Journal claimed the event was a "symbol of declining Communism." Sing Tao Jih Pao (Sing Tao Daily) from Hong Kong cheered on every victory and showed extreme concern for every setback because "today's Beijing would be tomorrow's Hong Kong."

\section{Purpose of Study}

This thesis studies the differences among Chinese-language newspapers from Taiwan, Hong Kong, and China through a content analysis of their day-to-day coverage of the Chinese student democracy movement in the spring of 1989. 


\section{CHAPTER II \\ LITERATURE REVIEW}

\section{News and Reality}

In his study of newsmaking processes, Hall (1981) noted that news is not "newsworthy people and events happening 'out there' in the real world," but a product of the news construction process. In Making News, Tuchman (1978) described news as the construction of reality rather than the reality itself. News might have reflected the society but it "presented to a society a mirror of its concerns and interests" (p. 183). Yet news did interpret the society. It led the audiences to peek at the world through a window-frame, which was composed of the ideological codes and professional guidelines that newsmakers had applied during the process of making the news. News also helped to constitute the society as a shared social phenomenon, because "in the process of describing an event, news defines and shapes that event" (Tuchman, 1978).

In the construction of news, many factors influence the process. There are factors at the individual level, including journalists' professional values, norms, stereotypes, and judgments; factors at the organizational level, including the organizational structure and routines of news operations as well as economic and technological constraints; and factors at the societal level, including the political, economic, and social systems within which the news media operate (Gans, 1979; Hall, 1981; Shoemaker \& Reese, 1991; Tuchman, 1978; Turow, 1992).

Smith (1973) pointed out that the news' view of the world could not by its nature be an objective-realistic view: "A society which demanded its news from 10 separate perspectives would not be receiving news. Ten views of reality do not between them add up to a new 'objectivity' to exchange for an old one" (p. 73 ). Because reality is abstract-- 
political philosophies, and international strategies--and can not be directly televised like a demonstration, news is not organized to give accounts of this reality. Instead of recognizing the world as being one of many interacting processes, news splits it into innumerable small pieces of facts and discrete stories. Birt and Jay (1975) thus argue, in their criticism of television news, that a large number of stories are presented in a narrow and limiting way. The selective pictures--small pieces of facts and discrete stories-presented in the news misled and confused the audience (Glasgow University Media Group, 1976).

Because of these factors, journalists can hardly maintain a truly neutral position; they implicitly and explicitly blur the line between fact and interpretation. They select, compress, and simplify reported events. There is the inherent problem of the relationship between language and reality.

The media, as any social institution, does not operate in isolation. The newsmaking process is affected by all the realities of the environments in which the media exist: historical, political/ideological, social, cultural, and economic (Altschull, 1984). Pertinent to this thesis is the relationship between ideology and the press. Ideologies are structures through which the subjective reality of things is fashioned and meaning is imposed on the social world (Chibnall, 1977). Ideologies are the connecting link between the so-called "facts" of the news and the background assumptions that enable the audience to understand those facts. Ideology is thus a "background" to the news (Gouldner, 1976). In his study of the British press, Chibnall (1977) found that a basic component by which the press identify and interpret the news is "the framework of concepts and values which shape meaning of the event, rendering it understandable in the terms of the ideological system" (p. 12). Golding (1974) noted that the mass media are an integral part of political life and "the communication can be overtly and purposively political, with a deliberate intent to persuade 
(i.e., policy and campaigns), or it can be only incidentally political (i.e., ideology and inferential structures)" (p. 79).

Various ideologies shape different types of social systems and mass media systems, and these different systems, in turn, create a range of social perspectives which influence the society on how to assure the practice of an ideology, how to value a social system, and how to judge an event.

Altschull (1984) argued that the press is simply a political institution: "When it is said that the press (in the United States) is above politics, what is often meant is that the press is above partisan politics"(p. 285). He noted that, in all press systems, the news media are agents of those who exercise political and economic power and the content of the news media always reflect the interests of those who finance the press, be they the audience or the government.

In short, news is the construction of reality, not the reflection of reality. Ideology, as one of the critical social factors, influences the newsmaking process and helps shape the news. In light of these theories, this study examined the Chinese-language newspapers from China, Taiwan, and Hong Kong, respectively, and the relationship between their political ideologies and their news coverage.

\section{Political Ideologies and the Press in China, Taiwan, and Hong Kong}

Although they have a cultural tradition in common, political ideologies distinguish the socio-political systems as well as the Chinese press in China, Taiwan, and Hong Kong. Each region's press is largely determined by its social-political context and, in turn, its functions are compatible with its national political ideology (Chang, 1989). The following is a brief description of the press and media environments in these three regions.

The Press in China. In contrast to the American market-oriented, "watchdog" enterprises, Chinese newspapers are owned by and under the control of the Chinese 
Communist Party and the government. In China, "newspapers are considered as political and propaganda weapons for carrying out the ideological struggle and are the tools for building socialism" (Liu, 1982, p. 47).

According to Mao Zedong, the late chairman of the Chinese Communist Party (CCP), the functions of the mass media are to publicize Party decisions, educate the masses, and form a link between the Party and the masses. Through the mass media, the Party strives to develop in the people the socialist characteristics that will make them loyal and useful citizens of the country. The mass media must therefore become the Party's "loyal eyes, ears, and tongue" as well as a powerful instrument for the Party to guide socialist revolution and construction. In other words, the press has a mission to inform the people about government policy; to educate them and agitate them to progress; and to form and direct their opinions (Chang, 1989; Houn, 1956).

The policy-making and information delivering functions are controlled by the propaganda leading group of the Central Communist Party Committee (CCPC) Secretariat. It has direct organizational control over high level media institutions, including the Propaganda Department of the CCPC, Xinhua News Agency, and People's Daily (see Table 1). It also controls the local level of media through a registration system as well as the single authoritative news agency, Xinhua News Agency, which supplies international and national news to all newspapers and broadcasting stations in China. Beyond the single governmental news agency that controls the collection and distribution of news, explicit restrictions are also in place to forbid reporters on the local level to cover any high level events or sensitive issues, including the CCPC conference and the visits of world leaders (He, 1993, 1994; Lent, 1982). 
Table 1

Hierarchy System of the Chinese Media (He, 1994)

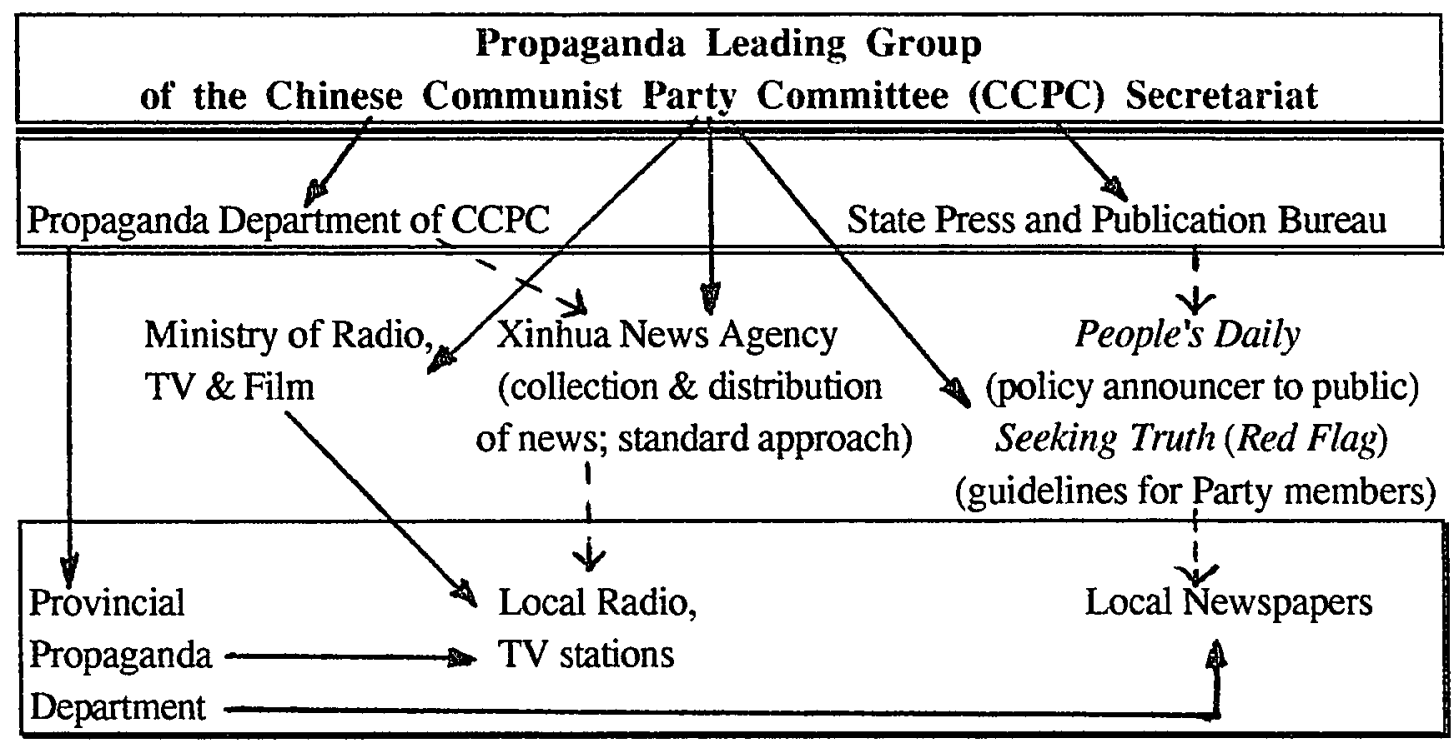

More than half of those who work for newspapers are party members (Chang, 1989).

All party members are obligated to follow the party line, to adhere to the principles of Marxism-Leninism and "Mao Zedong's thought." The newspaper workers have two roles to play: making news as well as making sure the newspaper follows the party policy. Though journalists in mainland China also function to reflect different voices, the most fundamental requirement is to take a clear stand, and to uphold the basic viewpoints of Marxism and the Party's policies, according to late Party General Secretary Hu Yaobang (Chang, 1989).

Carrying criticism and self-criticism in newspapers is an important task that newspapers are obliged to do. A People's Daily commentary on December 22, 1985 noted that "conducting criticism and self-criticism has played a positive role in improving our work, the style of work of the Party, and the general mood of society" (Chang, 1989, p. 104).

News in China is anything that can be used to illustrate current party policy or 
economic progress. Both the reporting of news and its consequences need to be in accordance with the party policies and ideologies. Like its big brother, the former Soviet Union, China also operates under the assumption that "news should not be merely concerned with reporting a particular fact or event. News or information must pursue a definite goal: it must serve and support the decisions related to fundamental duties facing the society" (Lendvai, 1983, p. 69).

Although the Chinese press has a tradition of working in a tightly controlled organizational environment, in the 1980s it exhibited some independence because it was able to take advantage of China's open-door policy after being shut out from the rest of the world for four decades. In an effort to explore its new role as the country strived for economic and technological modernization, the Chinese press struggled for press autonomy (Public Opinion Research Institute of the People's University, 1989). Although the concept of freedom of speech was warmly welcomed by many Chinese journalists during the 1989 pro-democracy movement, it greatly disturbed the policy makers (Liang, Tam, Liu, Chan, \& Ma, 1989). After using military force to crack down on the 1989 prodemocracy movement, China's government called for a national movement to cleanse the society of Western ideologies and bourgeois liberalism $(\mathrm{Li}, 1989)$. Although the Chinese press continues to face many obstacles in its quest for more independence and freedom, it has nevertheless made some remarkable progress in the last decade (He, 1993). The coverage of the 1989 pro-democracy movement in People's Daily is an example of such struggle and progress.

The press in Taiwan. To understand the press in Taiwan, one must understand that it evolved from the intra-linked triple alliance of the ruling Kuomintang (the KMT, or the Chinese Nationalist Party), the government, and the military, a bureaucratic-authoritarian regime tightly controlled by Chiang Kai-Shek and his son, Chiang Ching-Kuo (Lee, 1993). 
Taiwan considered itself as being at war with China since the KMT lost the mainland in 1949 and fled to Taiwan. "In the name of anti-Communism, the KMT imposed the world's longest martial law on the island between 1949 and 1987" (Lee, 1993, p. 3). In addition, there were the existence of the publication law and political taboos the press had to abide by (Chu, 1982; Hu, 1973). The publication law listed three offenses:

1. Sedition and treason.

2. Committing or instigating others to commit offenses against religion and the dead, or against public morals.

3. Committing or instigating others to commit offenses against or interfering with the lawful exercise of public functions or with voting, or offenses against public order.

Taboos in the Taiwan press included any criticism of the government's basic policy of recovering mainland China, disrespect to Chiang Kai-Shek, anything that might have a demoralizing effect, and anything that might assist Communist propaganda (Chu, 1982). If any of these violations occurred, the Ministry of the Interior was authorized to give warnings, to impose a fine, to prohibit the sale and distribution of a publication, to suspend the publication, and even to revoke the registration of the publication (Chang, 1968).

To keep the press in line, the KMT approached the press with obvious yet rigorous rewards and punishments accrued to press owners. A press ban declared in 1951 froze registration of new press licenses until 1987. Among the 31 newspapers that existed before 1987 , more than half were in the hands of the KMT-government-military while most of the rest depended heavily on public (government) subsidies. The two financially self-reliant private newspapers also developed into pro-KMT organs after both publishers were recruited into the Standing Committee of the KMT's Central Committee (Lee, 1993). One of the two is the United Daily News group which launched the World Journal that was studied in this thesis.

In Taiwan, there was no press censorship by law but there was pressure from the 
government: "There was the ever present prospect of pressure from the administrative powers to punish newspapers without due process of law and the potential pressure from some bureaucrats disliking a news story or editorial and the newspaper being warned or even confiscated" (Hu, 1973, p. 39). Martial law legalized the KMT's reliance on military and police forces to suppress the press. In 1979 Chiang Ching-Kuo turned to the secret police to set up an office that surpassed all government and party agencies in power. Among other duties, this group of Chiang's confidants systematically campaigned to create doubts about liberal critics and black out undesirable news. Joining them in killing stories were many KMT officials who made calls to publishers right before deadlines (Lee, 1993).

The death of Chiang in Taiwan and Mao in China in the mid-70s led to a warmer political atmosphere between the two regions in the 1980s. In 1987, after decades of an opposition movement and the continuous effort of the private and underground press, the Taiwanese government lifted martial law as well as the press ban. The two decades of stable economic prosperity also contributed greatly to such a change.

Taiwan's press reform, along with its political transition in the $1980 \mathrm{~s}$, led to the end of a number of previous taboos. Most dailies began to include a page devoted to mainland Chinese affairs and news. Some newspapers began setting their type horizontally, left to right, which was previously rejected mainly because it is the standard for Communist Chinese newspapers. Although they have stopped attacking each other in the manner of a cold war, the two governments still carefully guard their territory, not only that of geography but also of politics, the international market, and social ideology. During the Chinese student demonstrations in the spring of 1989, this traditional political antagonism again revealed itself in Chinese-language newspapers in Taiwan as well as in the United States.

The Press in Hong Kong. Hong Kong is a British colony of contradictions, in 
which there is a mixture of modern economy and archaic polity and in which the media are free yet restrained, apolitical yet partisan. In 1842 Britain captured Hong Kong from China and in 1997 Britain will hand over its last colony to China. Today Hong Kong is undergoing a transition to become a capitalist region that will be part of a socialist China. The constant presence of the China factor has set a "severe limit on what Hong Kong can do in the way of colonial politics"(Chan \& Lee, 1991, p. 5). Traditionally Hong Kong has always been a refuge for Chinese politicians trying to stay away from the turmoil in China (Lam \& Tam, 1990). After the 1949 settlement of the Chinese civil war between the Communists and the Nationalists, Hong Kong became the battleground of these two parties and their ideologies. To absorb the pressure from its giant neighbor, the Hong Kong government has attempted to stay neutral in the feud between the Communists and the Nationalists by allowing each party to set up its propaganda organs as long as they stayed within the confines of the law and did not threaten the legitimacy of British rule (Chan \& Lee, 1991).

Hong Kong has no grass roots democracy. It is an administrative state. The colonial government co-opts the political forces, often represented by industrial-commercial elite groups, into an administrative decision-making body, thus achieving some level of elite integration (King, 1975). However, the press in Hong Kong enjoys freedom second only to Japan in Asia. This press freedom is more an absence of explicit government censorship than a right to participate in democratic politics. It is extended primarily with reference to the contending Chinese political parties, not toward the colonial government itself. This freedom may attribute its source to the lack of reinforcement of the anti-liberal Publications Consolidation Ordinances that the British enacted in Hong Kong in 1949 (Chan \& Lee, 1991). Hong Kong not only hosts the biggest Chinese population outside mainland China and Taiwan, it is also the only place where the Chinese-language press enjoys considerable 
press freedom (Chang, 1982).

The most obvious characteristic in the Hong Kong press is party-press parallelism: the press is linked closely to party organizations, identifies with party goals, and caters to partisan audiences (Seymour-Ure, 1974). Hong Kong's party-press parallelism is not rooted in local politics but is a reflection of modern Chinese party conflicts between the Communists from China and the Nationalists from Taiwan (Harris, 1978). Ideologically, Hong Kong's newspapers span the full range of ultra-leftist, centrist, rightist, and ultrarightist, with its main political landscape to the right of center. The four types of press ideology are defined by the political tendency of each newspaper. Although the ultra-leftist newspapers include those that act as China's propaganda mouthpieces under Xinhua News Agency's supervision, the ultra-rightist ones are owned by the Nationalists' propaganda arm in Taiwan (Harris, 1978).

Summary. In conclusion, the Chinese press in mainland China is owned and controlled by the Communist Party, and is also a part of the official administrative system that serves the interests of government. The Chinese press in Taiwan, though some are owned by private enterprises, is closely related to the Nationalist party and the government of the Republic of China. Enforced for almost four decades, martial law and a press ban, along with political taboos, helped the Nationalists and the Taiwanese government control the press. Only the Chinese press in Hong Kong has the opportunity to be independent economically and politically.

These differences exist in the Chinese press in the above three regions and they are likely to exist also in the Chinese-language newspapers in the United States. This is the focus of this study.

\section{Background of the Three Chinese-language Daily Newspapers}

Three foreign-linked Chinese-language dailies were selected for this study. Each 
represents a region from which it originates and still relates to closely: Sing Tao Jih Pao represents Hong Kong, the World Journal represents Taiwan, and People's Daily represents mainland China. All three daily newspapers are overseas editions of their parent newspapers or newspaper groups, although local advertisements and local news are often added. Among newspapers from these three areas, those from Hong Kong tend to be the closest to the center in their editorial slant on news about Taiwan and China.

Few studies have been done on these foreign-linked Chinese-language newspapers in North America. In 1973, Yuan-Yuan Hu analyzed Chinese newspaper coverage of China's admission into the United Nations and found that, while the Hong Kong newspaper Sing Tao Jih Pao gave comparatively objective reportage, Taiwan's Central Daily News and China's People's Daily either neglected or attacked each other's activities. But since then, many events have occurred. Britain agreed to return Hong Kong to China in 1997 and Hong Kong has since begun its political transition. There have been political and economic reforms in both Taiwan and China following the death of Chiang Kai-Shek and Mao Zedong. And above all, the Tiananmen Square massacre occurred in the spring of 1989 following the Chinese students' pro-democracy demonstrations. These issues are common concerns for Chinese-Americans, as well as the Chineselanguage newspapers in the United States. Thus there is a need to re-examine their present status.

In late 1982, Tsan-Kuo Chang content-analyzed a six-day sample of eight Chinese daily newspapers in the United States to determine the role and functions of the Chinese-language press in America. Chang found the Chinese-language press did not pay much attention to the local Chinese communities. Instead, the papers gave a large amount of space to coverage of China, Taiwan, and Hong 
Kong--the three homelands of the Chinese immigrants in America. The findings suggested that the Chinese-language newspapers in North America serve as a link to the past for the Chinese immigrants who came to the United States from China, Taiwan, and Hong Kong (Chang, 1983). Because of this linkage function, whatever happened back home would be of common concern and a hot topic in these newspapers. The Chinese student demonstrations in Beijing in 1989 were part of these concerns.

Background of Peoples Daily (China). People's Daily is the Chinese counterpart of Pravda. It is the most influential party newspaper in mainland China, not only because it reaches everyone there directly or indirectly but also because it is the organ of the Central Committee of the Communist Party of China. Founded on June 15, 1948, this national newspaper published in Beijing has a circulation of 5 million and a readership estimated at 30 million (Chang, 1989; MacFarquar, 1973).

Instead of reporting hard news, media in Communist countries are devoted to forming standard political opinions (Lendvai, 1983). "It is the ambition of Chinese leaders to use the mass media 'to alter reality by influencing the perspective of the observer' so to realize (the observer's) vision of a 'good society'" (Liu, 1982, p. 48).

Criticism and self-criticism are obligations of all newspapers in China, and People's Daily is expected to set the leading example. At the same time, it is believed that criticism and self-criticism can help invigorate the paper, raise its prestige, promote its status in the Chinese media, and improve the work of the Communist party and the general society.

Criticism in newspapers, like public opinion, creates a very powerful social pressure on the individuals who have been investigated and criticized. Because People's Daily is the party's mouthpiece, its criticism is more powerful, and creates more fear in the masses. For example, in the early 1980s, a deputy editor of People's Daily, Wang Ruoshui, contended 
that both the theory and practice of socialism had yet to be perfected and he had a leading liberal voice on a variety of opinions while others kept quiet. Wang was later removed from the editorial post, following a self-criticizing editorial in People's Daily (Chang, 1989).

People's Daily has a total staff of 600 , with more than 30 correspondents stationed in the major Chinese cities and 25 stationed in foreign cities such as Washington, DC, New York, and Paris (Chang, 1989).

The overseas edition of People's Daily was established in July 1985. Although it follows the same ideological principles in its production, it varies in its format and content to target the entire Chinese-reading public outside mainland China--overseas Chinese, foreigners of Chinese origin, foreigners who read Chinese, and Chinese who work or study outside China. It is prepared and edited at its headquarters in Beijing and the pages are then transmitted via satellite to San Francisco, New York, Tokyo, Paris, and Hong Kong for reprinting and distribution in surrounding areas. The purpose of this edition is to "relay the major editorials and reports of the People's Daily to overseas readers, transmit the most important policies of the Communist Party and the Chinese government, and inform the readers of what is happening in China" (Chang, 1989, p. 95).

Background of the World Journal (Taiwan). The World Journal is one of the several affiliated newspapers of the privately owned and operated United Daily. Founded in Taipei in 1951 by Wang Tih-wu, the United Daily has grown into Taiwan's largest newspaper publishing group (Republic of China Yearbook, 1989).

Major Taiwan newspaper publishers entered the American market during the 1970s. In 1976, the United Daily, a well-financed newspaper connected with powerful central committee members of the Nationalist party in Taiwan, began publishing the World Journal in New York and San Francisco. It established several operations with local staffs 
for covering news in North American. In 1984, the World Journal claimed the highest circulation among Chinese-language newspapers in the United States (Miller, 1987).

Background of Sing Tao Jih Pao (Hong_Kong). Sing Tao Jih Pao is a conservative Hong Kong daily founded in 1938 by Aw Boon Haw. In the 1960s, it reached a circulation of 200,000 (Miller, 1987). It owed its success in circulation and advertising to the vibrant Hong Kong economy that ultimately depended on political stability. However its eminent position in the market has been overshadowed by some newspapers founded in the 1950 s and 1960s. Its circulation dropped to 50,000 with a readership of 131,000 in the 1980 s (Chan \& Lee, 1991).

In 1961, Sing Tao Jih Pao edited its first overseas edition. which was a condensed copy of its Hong Kong edition air-mailed overseas. In 1964, Sing Tao Jih Pao launched its first North American edition through a San Francisco export-import firm. At that time news and feature articles were typeset in Hong Kong and flown to the United States where local news was added to complete the edition. Sing Tao introduced to North American Chinese-readers a higher standard of reporting and better writing than that previously found in local Chinese-language publications. Eventually, editions were published in New York, Los Angeles, Vancouver, Toronto, Alberta, London, and Sydney. In 1978, its satellite transmission project was completed to better serve its overseas offices all over the world.

According to the late publisher of Sing Tao Jih Pao, Aw Boon Haw, the paper is "to speak only for the public" and its "common aim is to provide a true and undistorted mirror of public opinion" (Chang, 1982). Most of its readers are Cantonese from Hong Kong and mainland China. Its U.S. West coast edition reaches as far as to Hawaii and Houston with a circulation of up to 35,000 daily.

\section{Previous Studies of Media Coverage on the Chinese Democracy Movement}

He (1991) noted that the 1989 Chinese pro-democracy movement was a media- 
aided movement. He found that the Chinese national news media were involved as a party in the conflict. Although "institutionally they were supposed to represent the government, individually many journalists sided with the students" (p. viii). As a result, they generated an inconsistent coverage of the movement at different times, which ranged from criticism to support of the movement and from a news blackout to comprehensive coverage.

Also, the Voice of America as a third party gave extensive coverage to the movement and devoted equal time to quotations from both sides. However, $\mathrm{He}$ (1991) argued that "the VOA clearly leaned toward the demonstrators" in the overall pattern and its tone of its coverage, which reflected American ideology and VOA's interest. He concluded that the Chinese national media and the VOA had a considerable impact on the movement, as well as being affected by the movement.

In their 1990 survey that examined the relationship between exposure to the news media and the knowledge of and attitudes toward the Chinese pro-democracy movement among the Chinese students, Zhu and He (1990) found that, after the declaration of martial law on May 20,1989, the students reduced their use of the Chinese media and increased their use of outside media. The Chinese media also lost credibility at the same time. The students in Beijing relied less on mass media and more on personal sources of information than those outside the city. However, these findings are largely limited by the skewed sample population (all subjects were young and highly educated) and the small size of the sample.

Chen (1990) used a qualitative content analysis to compare the coverage of the 1989 Chinese student demonstrations between April 15 and June 4, 1989 in The New York Times from the United States, Central Daily News from Taiwan, and People's Daily from China. The study focused on "the intention and effects of the media communication beyond the obvious, superficial content of the news reports" (p. 23). The findings showed 
that People's Daily failed to perform its duty as a news service, because it had "missed some essential elements of journalism in its reporting: truthfulness, fairness, comprehensiveness and timeliness" although it had "a brief period of openness during May 1989" (p. 86).

Another content analysis of the news coverage of the event was conducted by Jianmin Zhang (1990) to determine the coverage of themes and distribution of sources in People's Daily and The New York Times. The analysis, based on 3,638 paragraphs from 229 stories published in these newspapers between April 16 and June 11, 1989, found that the two focused on very different themes and relied on different sources. People's Daily relied almost entirely on government sources and concentrated on the Chinese government's attitude and announcements. In contrast, The New York Times relied on nongovernment sources for information and provided comprehensive coverage of the most dramatic events, namely, demonstrations, the power struggle among top leaders and the military rift.

In addition, Kangcong Zhang (1991) content analyzed the news coverage of the 1989 Chinese democracy movement in four major U. S. newspapers: The New York Times, The Washington Post, The Christian Science Monitor, and The Los Angeles Times. The findings indicated that the news stories published by the four newspapers tended to cite pro-student sources rather than pro-Chinese government sources.

Wang (1991) extended her study of news coverage beyond the content to factors that influenced the coverage. In her comparative analysis of media coverage of the 1989 Chinese student demonstrations in three capitalist countries/territory (the United States, France, and Hong Kong) and three communist countries (the Soviet Union, Vietnam, and China), Shujen Wang found that: "(1) political ideology played an important role in the direction, but not necessarily the extent, of the coverage of the events; (2) diplomatic 
sensitivity played an important role in the direction of coverage, especially for official or government media and it even ameliorated differences in political ideology; (3) cultural affinity did not necessarily produce positive news coverage; and (4) geographical proximity did not affect the extent nor the direction of the coverage as much as the political ideology and diplomatic sensitivity did" (p. i).

Another area of interest related to the media studies of the 1989 Chinese democracy movement is China's media reform. After many minor yet significant changes in the 1980s, China's media reform reached its peak in mid-May of 1989, only to be crushed after the June 4 massacre. Many China watchers were concerned that the media reform might have come to an end in China. Zhinian Zhang (1990) concluded that the media reform suffered a "temporary setback" because of the June 4 incident but it did not return to the dark ages. Although the media have achieved improvements in reporting techniques and gained more freedom in the reportage of non-political issues, there has not been any fundamental change in their nature and functions. Despite continuous economic reforms in China and the somewhat oscillatory control exerted by the government, fundamental change in China's media and the establishment of a free press law has not yet occurred.

\section{Research Questions}

As a result of differences in political ideology, concepts of news, roles of the press, media systems, and governmental regulation, the Chinese-language newspapers from mainland China, Taiwan, and Hong Kong differ. This study examined the relationship between the existing ideological backgrounds and the press coverage of the Chinese democracy movement in the spring of 1989. The research questions are as follows: (1)What differences, if any, were there in how three foreign-linked Chinese-language daily newspapers (People's Daily from mainland China, the World Journal from Taiwan and Sing Tao Jih Pao from Hong Kong) covered the democracy movement? (2) To what 
extent and direction does political ideology affect press coverage?

Although proximity and cultural affinity are also two major factors that often influence the news-making process, they are not very important in this study. Because both Hong Kong and Taiwan are physically close to China, all three regions and peoples share the same Chinese culture with subtle variations.

A review of potential factors that influence the coverage of each of these three newspapers is discussed below.

People's Daily is the mouthpiece of the Communist party. It is an institution tightly controlled by the government through control of its organizational system, financial support, and above all political ideology. Therefore, People's Daily was expected to praise those who obeyed the guidelines of Marxism and the policies of China's government, and condemn those who criticized the party and government, such as the 1989 demonstrators. However an individual journalist's ideology may not always agree with the political ideology, or the official ideology as in the case of mainland China. This disagreement in ideology was expected to emerge whenever the political atmosphere permitted it to do so. In modern Chinese history there were such relaxed moments--in 1956-1957, in the late 1970s and 1980s, and during the 1989 demonstrations. This indicated that there could be some possible variation in the People's Daily's coverage during the 1989 demonstrations.

The World Journal is affiliated with Taiwan's United Daily. Although it has been tailored to meet the interests of Chinese-Americans it continues to reflect the traditional antagonism between the Nationalist and the Communist parties that has not diminished. After lifting the 40-year-old martial law aimed at protecting Taiwan from the possibility of attack by China, today the country praises the theory of democracy and human rights.

Because of these factors, the World Journal was expected to attack the mainland Communist government and Communism. 
Sing Tao Jih Pao is independent both financially and politically. It represents the interests and concerns of Hong Kong. In the transition from a British colony to a capitalistic region of socialist China, individuals and businesses in Hong Kong worry about their fate after 1997 . The Beijing government's every move has been watched carefully by the people of Hong Kong. A better situation in today's Beijing might give hope for a better situation in Hong Kong tomorrow. Along these lines, Sing Tao Jih Pao was expected to pay close attention to the 1989 demonstrations and produce a large amount of coverage on it.

In addition to these overall trends, the three newspapers were expected to vary in many of the following aspects--the amount and the tone of coverage, placement and style of the stories, explanation of causes and purposes of the movement, and the description of reactions from the Chinese government and residents toward the movement. 


\section{CHAPTER III}

\section{METHOD}

The primary method of this study is a quantitative content analysis, because it is "a research technique for making replicable and valid references from data to their context" (Krippendorf, 1980, p. 21). In addition, the study provided historical background and a narrative account of the pro-democracy movement. Providing a clear understanding of a historical event in a narrative style is the important attribute of a historical analysis (Startt \& Sloan, 1989). It is necessary to present such a framework in the study of differences and agreements on media coverages.

Chapter 4 provides a context for the study and Chapter 5 provides an analysis of the result of the quantitative content analysis.

\section{Historical and Social Context}

To analyze the media account of the movement, it is first necessary to understand the social and historical context of the movement . Chapter 4 presents a narrative account of the event and a brief analysis of the social factors involved. The chronology provided in Chapter 4 supplements the content analysis presented in Chapter 5. The chronology is based on information from Facts on File, a World News Digest, and eyewitness accounts recorded by journalists from China, Hong Kong, and the United States. To ensure a neutral and objective chronology, only those incidents that were reported in at least two publications are recorded as part of this narrative account.

The impact of the May Fourth Movement in 1919 on the Chinese democracy movement in 1989 and the influences of the approaching 1997 transition on Hong Kong's participation in this movement were also some factors discussed in Chapter 4. 


\section{Content Analysis}

Sample. The content analysis was conducted on the Nortin American editions of three foreign-linked Chinese-language newspapers: People's Daily from mainland China, the World Journal from Taiwan, and Sing Tao Jih Pao from Hong Kong.

The study considered the content of news reports and editorials about the Chinese democracy movement both inside and outside of China during the Spring of 1989. Many terms have been used to describe the Chinese democracy movement in the Spring of 1989. These included "Beijing students' demonstrations," which limited the scope of the movement. Although Beijing, especially Tiananmen Square, was the focal point and the students were the most active player throughout the movement, participants included intellectuals and journalists, ordinary citizens, workers, and others in major cities across the nation. This movement also stretched beyond China's border to concerned residents in Hong Kong as well as to overseas Chinese worldwide. Therefore, the selection of items related to the movement for this study included press coverage of demonstrations in Beijing, in Shanghai, in Hong Kong, and in San Francisco.

Since this study looked into the coverage of an event, the sample was confined to a specific time period. The sample period began on April 15, 1989, which was the day former Party Secretary General Hu Yaobang died, and ended on June 10, 1989, which was eight weeks after the demonstrations began, and one week after the June 4 massacre. By June 10, "not only had the demonstrations ended, but the imposed martial law had made coverage of anything but government-sponsored events not only difficult but dangerous" (Huffman, et al. 1990, p. 8).

A total of 3,521 news items were coded for the content analysis. With the exception of 6 missing issues out of 154 issues that were published, the content analysis included all items about the democracy movement from the three Chinese-language newspapers during 
the eight consecutive weeks between April 15 and June 10 in 1989. The World Journal published seven days a week, while both People's Daily and Sing Tao Jih Pao printed only six days a week. Because of the large volume of this sample and the choice of "daily news hole percentage" as a measurement, the difference in the number of days sampled among the three newspapers was considered very minimal.

Measurement. The unit of analysis was the individual news story--both hard news and features--or editorial, or advertisement that was related to the Chinese student movement in the Spring of 1989 both inside and outside of mainland China, not limited to those that happened in Tiananmen Square. A news photograph or a group of photographs under one single caption, or an advertisement was also included as one item if its content was related to the movement. A news story or editorial under a single headline was counted as one unit. A news story or editorial continuing to another page was counted as one item. A big headline across the page was measured as part of the most-related story on the same page.

In the attempt to describe the relative emphasis in the content of the newspapers, the surface area was measured in square centimeters to determine the amount of space given to a particular story, or a particular theme in one story. Square centimeters of the headlines were also included in the measurement. The measurement of each story was rounded to the nearest centimeter.

Coding categories and operational definitions. The following categories were used in the content analysis of the coverage of the three newspapers on the Chinese student movement between April 15 and June 10, 1989. Each issue of these three newspapers in this period was measured and coded using the following categories.

1. Total number of stories and amount of coverage. This category provided a measure of the total number of stories and the volume of coverage in the three newspapers. 
The unit of analysis for measuring the total number of stories was the individual story described above in the measurement section. Then, the areas in square centimeters of all selected items, including news stories, features, editorials/commentaries, photographs, and advertisements were measured and the types of coverage were coded.

2. Placement. This category provided data on what page the item was placed. The number of items displayed on each page was recorded and totaled. The result, which was calculated to determine the percentage of items placed on each page, provided a measure of the place or importance of the coverage.

3. Type of item. This included five categories: news, feature, editorial, photograph, or advertisement. Both hard and soft news were coded as news stories. Features included backgrounders, human interest stories, and profiles. All opinion-oriented items including commentary, editorial, analysis, and speeches were coded in the editorial category. All photographs and advertisements related to the Chinese student movement were also coded in the same manner.

Advertisements were not originally selected as a measure in this study since advertisements are rarely related to a news event. However, towards the end of May at the peak of the movement, many Chinese in Hong Kong and the United States put out page after page of announcement ads to publicize local demonstrations in support of the students in China. After the June 4 massacre, even more advertisements were used by groups and individuals to condemn the bloody act of the Chinese government. Because the content of these advertisements was directly related to the student movement, they were included in this study as a type of coverage.

4. Labeling the movement. This variable measured how each newspaper described the Chinese democracy demonstrations when they were covered. Key words were developed to categorize the references into four groups: positive, neutral, moderately 
negative, and very negative. For example, referring to the demonstrations colorlessly as marches and rallies, was coded as neutral; as pro-democracy movement or patriotic acts was coded as positive; as disturbances or riots was coded as moderately negative; and referring to the demonstrations as turmoil and counter-revolutionary was coded as very negative.

5. News sources. This described where the stories originated. The five categories established were: stories reported by reporters of the newspapers or its affiliated news group; stories collected from other Chinese newspapers or news groups; stories from the major Western news agencies such as AP, UPI, or the New York Times; stories from China's only official news agency, Xinhua News Agency, or speeches of Chinese officials; and stories from special individual contributors such as columnists or known scholars.

6. Causes of the movement. This explained what the causes of the movement were when each newspaper covered activities in the student movement. In other words, this described each issue that led to another wave of demonstrations. Issues like Hu's death, unfair judgement of Hu's status, and a People's Daily's editorial fluctuated with the amount of coverage. Categories of causes were "mourning of Hu's death," "exploration of democracy," "demands for democracy," "indifference of government towards demonstrators' requests," "repression of the movement, both verbal attacks and physical violation" and "manipulated by a few black hands (ring leaders)."

7. Purpose of the movement. This explained how each newspaper portrayed the purpose of the movement when it covered the demonstrations. Categories selected were "mourning Hu's death," "democracy," "correction of existing corruption," "freedom of speech," "riot," and "anti-government or anti-revolution."

8. Government's reaction toward the demonstrations. This covered what action or attitude China's government took against the demonstrators both at Tiananmen Square and 
elsewhere inside mainland China, according to the description of each newspaper.

Categories used were "criticism of the demonstrations," "neither criticism nor approval of the demonstrations," "both criticism and approval of the demonstrations," and "approval of the demonstrations."

9. Ordinary citizens' reaction toward the demonstrators. This covered how each newspaper described the general residents' action and attitude towards the demonstrators. Categories for this measurement were "criticism of the demonstrators," "neither criticism nor approval of the demonstrators," "both criticism and approval of the demonstrators," and "approval of the demonstrators."

10. Coverage of the key players in the movement. This measured the amount of coverage each of the following key players had in each of the three newspapers, respectively: Chinese students in China; Beijing government; ordinary citizens; journalists and intellectuals; workers and merchants; the military and the police; non-Communist associations (including both political and religious groups); Hong Kong government, residents and celebrities; Taiwan government, residents and celebrities; overseas Chinese (those living outside of China yet not in Taiwan, Hong Kong); Western countries and Japan; and Communist countries.

11. Typical themes. This was meant to highlight the relations among China, Taiwan, and Hong Kong, with categories like "the movement's impact on Hong Kong," "the movement's impact on Taiwan and the unification of China" and "the partisan reportage of the government controlled press in China." However, the coding failed to generate enough meaningful content in these categories because most of the stories were not focusing on these themes at all.

12. Layout. This recorded any eye-catching effects that were used in the layout of a story. A prominent story often was presented with one of the following: colorful headline, 
extra large fancy fonts, and unique border plus shaded headline.

Six time periods. The coverage was divided into six time periods between April 15 and June 10,1989 . The following time periods were used to generate more meaningful findings.

1. April 15 - April 25: Demonstrations and other activities led by the public's concern about $\mathrm{Hu}$ (i.e., his death; judgment of his status).

2. April 26 - May 3: People's Daily called the demonstrations riots in its editorial, igniting more massive demonstrations nationwide.

3. May 4 - May 16: Opinions were split among the government leaders and a student hunger strike began after demands for dialogue between government and students failed.

4. May 17 - May 19: The hunger strike continued until a visit by Party Secretary General Zhao Zhiyang and Premier Li Peng and more massive demonstrations were held in support of students.

5. May 20 - June 2: Martial law was enforced, more support came from the masses and from overseas and the military surrounded Beijing.

6. June 3 - June 10: The June 4 massacre occurred, martial law continued, some demonstrations occurred, demonstrators were arrested and some government leaders were demoted.

The following chapter, Chapter 4 , provides further discussion on these six time periods and the development of the movement.

Intercoder reliability. Ten percent of the total sample of news stories or editorials were randomly selected from each of the three selected newspapers from April 15 through June 10,1989 . Using the definitions and categories above, two coders coded all 350 stories independently. Scott's $p i$ index, 


$$
\mathrm{pi}=\frac{(\% \text { observed agreement }-\% \text { expected agreement })}{(1-\% \text { expected agreement })}
$$

was used to measure the percentage of agreement among coders (Wimmer \& Dominick, 1991, p. 173). The intercoder reliability coefficient was .85 . 


\section{CHAPTER IV}

\section{CHINESE DEMOCRACY MOVEMENT: AN OVERVIEW}

The 1989 Chinese student movement involved thousands of Chinese students and other Chinese both inside and outside of China. As a result of the technologies of the modern media, the movement's dramatic developments--along with its democratic attributes--attracted global attention.

During the movement, the media competed to give their versions of what was happening and to predict what would be happening next. Since then, many writers have rushed to publish their memoirs and analyses of the movement. Because of the complexity and the scale of the movement, unfortunately, the news coverage articles and books often differed in their interpretation of what happened. Some differences can be easily explained by a narrow approach one writer took or a subjective and skewed perspective one had of the events. This can also explain why the Chinese official newspaper, People's Daily, intentionally ignored some facts and skewed certain opinions. But prior to any further discussion of coverage of the movement, it is necessary to provide an objective narrative of the events and the social context in which this movement occurred. This purpose of this chapter is to provide an account of the events leading up to the June 4 massacre and some historical background information.

\section{Chronology of the Chinese Democracy Movement in 1989}

The chronology presented here covers the 57 days between April 15 and June 10, 1989. Although the origins of the movement included many factors stretching as far back as the May Fourth movement in 1919, most people marked April 15, 1989 as the beginning of the 1989 Chinese democracy movement. It was after learning about former 
Party leader Hu's death on this day that a series of massive pro-democracy protests and rallies began.

April 15-April 25, 1989. During this period, Beijing students initiated the first wave of demonstrations and other activities to express the public's concern about Hu's death and the official judgment of Hu's status.

After being forced to resign as Communist Party general secretary in January 1987 for failing to crack down on student unrest, Hu had become something of a hero to Chinese intellectuals and liberal reformers. Hours after his death, students at Beijing University began hanging large-character posters mourning $\mathrm{Hu}$ and suggesting that "the wrong man died." The poster protest also occurred at other universities in the Chinese capital. Demonstrations started on April 16 in Shanghai and Beijing. They grew fast as the days went by and attracted thousands of students and onlookers into Tiananmen Square (Hitchings, 1989; Yi \& Thompson, 1989).

Wreaths were placed under the Monument to the People's Heroes in the Square to mourn $\mathrm{Hu}$, and a predawn sit-in was staged in front of the Zhongnanhai compound that houses the offices and residences of top government leaders; students demanded a dialogue with Premier Li Peng. By April 20 the demonstrations spread to Nanjing, Wuhan, Shanghai, and other major cities across the country.

On April 22, ignoring the official's warnings to clear the Square, 100,000 students and supporters gathered and commemorated Hu outside the Great Hall of the People where the official memorial service was held. The demonstrators called for political reforms including freedom of the press, speech, and assembly and demanded a meeting with government officials. All of these requests were ignored by the officials. On the same day, riots were reported right after the televised broadcast of Hu's memorial service in Xi'an and Changsha, two provincial cities in China. 
Thousands of Beijing students began an indefinite boycott of classes on April 23 that was supported by many professors. On April 24, an outspoken newspaper based in Shanghai was banned after it printed articles criticizing the government and supporting the students' demands for reform (Hitching, 1989; Simmie \& Nixon, 1989; Yi \& Thompson, 1989).

April 26-May 3, 1989. A harsh editorial that was published by the People's Daily on April 26 accused the students of creating turmoil. "The whole nation must understand clearly that if we do not resolutely stop this unrest, our state will have no calm days. This is a grave political struggle facing the whole party and the people" (People's Daily, April 26, 1989, p. 1). The government also warned against continued protests. The editorial ignited more massive demonstrations nationwide. On the same day in Shanghai, the editor of the World Economic Herald was dismissed for publishing an article commemorating $\mathrm{Hu}$ and criticizing the sacking of $\mathrm{Hu}$. It was an "account of his serious violations of discipline" (Hitchings, 1989; Yi \& Thompson, 1989).

In defiance of the People's Daily editorial, on April 27, more than 100,000 demonstrators, cheered on by half a million workers and citizens, marched through human barricades formed by the police for more than 12 hours, forcing the government to agree to a dialogue with the students. At this stage, the demands were expanded to include relief from inflation and an end to official corruption (Hitchings, 1989; Landsberger, 1990; Yi, 1989).

Chinese government officials on both the state level and the municipal level met on April 29 and April 30 with groups of hand-picked student representatives, which were dismissed by many students and a newly founded yet unofficial Beijing Students' Autonomous Federation (BSAF). Students handed in a list of petitions to the politburo of the government and gave them 24 hours to reply or face demonstrations on May 4. The 
petitions called for a new and televised dialogue between the representatives chosen by the students and high-level officials. But the government formally rejected the petitions and refused to recognize the BSAF as a legal organization.

Meanwhile leading intellectuals were voicing their support for the students. Shocked by the World Economic Herald incident, more than a hundred reporters from People's Daily demanded a dialogue with their highest management (Sixty-four HK Journalists, 1989).

May 4-May 16, 1989. During this period, massive demonstrations were joined by tens of thousands demanding democratic reforms. Hunger strikes were started by the students as demands for dialogue between the government and the students were rejected.

Up to 100,000 students and workers joined by hundreds of supporting journalists and intellectuals protested official corruption and called for freedom of speech while commemorating the May Fourth Movement. Several hundred Chinese journalists staged a demonstration of solidarity outside the headquarters of the official Xinhua News Agency in Beijing and a petition carrying 1,013 signatures of journalists was delivered to the All China Journalists Association. The petition marked the first time in China's history that journalists openly demanded a dialogue on press reform with Party leaders in charge of propaganda work.

During this period, opinion split between the reformers and the hard-liners in the Chinese government on their perceptions of the student demonstrations. In the Asian Development Bank meeting, Party Secretary Zhao Ziyang declared that "the just demands of the students must be met" and that "we should solve the problem in a democratic and legal way." A few days later, Zhao reconfirmed the patriotic nature of the student movement and proposed to the politburo standing committee that the April 26 People's Daily editorial be retracted. His proposal was voted down four to one (Landsberger, 1990). 
It was also during this period that hundreds of foreign journalists gathered in Beijing to cover the first Sino-Soviet Summit since 1959. That gave the protesters an international media stage; the state-controlled Chinese press had initially given only scant coverage to the unrest.

May 17-May 19, 1989. During this period, more than 1 million people twice took to the streets of Beijing to support the students and a hunger strike continued until visits were made by Party Secretary General Zhao and Premier Li. However, students declared that they would resume the hunger strike within hours of ending it when they learned that the possibility of Martial Law was approved and that Premier Li had again accused the students of creating turmoil.

A broadcast dialogue, held between student representatives and Premier Li broke off because of Li's refusal to discuss the students' demands.

May 20-June 2, 1989. During the period, martial law was enforced. More support came from the non-student masses nationwide and from overseas; more and more military units surrounded Beijing (Hitchings, 1989; Landsberger, 1990).

On May 20 martial law was declared by Premier Li, troops were brought in to clear out the protesters, and satellite transmission to foreign countries was halted. Martial law forbade any marches, rallies, strikes, boycotts of classes, or interviews. This stirred up waves of massive demonstrations to protest the declaration of martial law. More than 1 million people demonstrated in Beijing, tens of thousands in Shanghai, hundreds of thousands in Guangzhou and Xi'an, and similar rallies were also held in more than 20 cities across China (Hitchings, 1989; Landsberger, 1990; Yi \& Thompson, 1989). On May 30 , at the height of these demonstrations, the Goddess of Democracy was erected in Tiananmen Square.

In Hong Kong, 1 million people marched through the central business district and 
expressed support for the Beijing demonstrations. Hong Kong entertainers staged a 12hour benefit concert and collected HK\$12 million (roughly \$1.5 million U.S. dollars) for the Beijing demonstrators. The situation in China triggered an $11 \%$ drop in the Hong Kong stock market on May 22, the largest one-day fall experienced by the market since the 1987 worldwide stock market crash (Hitchings, 1989; Sixty-four H. K. Journalists, 1989).

Around the world, overseas Chinese held sympathy rallies in major cities including Paris, London, Tokyo, Los Angeles, San Francisco, and Washington, DC.

The increasingly heated internal struggle among Chinese party leaders was strongly felt but not confirmed. This resulted in inaccurate reporting in the Chinese press in Taiwan, Hong Kong, and the United States and spread rumors in Chinese communities as well as among China observers.

June 3-June 10, 1989. From the night of June 3 through dawn of June 4, the massacre took place. During this period, martial law continued, some demonstrations occurred, massive arrests of demonstrators began, and shake-ups in the Party leadership were announced.

As the military forced its way towards Tiananmen Square on the night of June 3 and cleared the Square with gunshots and violence, the seven-week-old democracy movement came to a halt. Casualties were reported to be in the thousands by Hong Kong and Western media although the Chinese government admitted that only a few hundred were killed (Sixty-four HK Journalists, 1989; Morrison, 1989).

The massacre was condemned worldwide and protests erupted in numerous cities across China. However, nationwide massive arrests of demonstrators and those who supported the demonstrations started within days of the massacre. Among those arrested, a few were executed and some were sentenced to years of imprisonment.

One hundred thousand concerned Hong Kong residents, all dressed in black, rallied 
to protest the massacre. The Hong Kong stock market dropped $22 \%$ as traders reacted to the event (Sixty-four HK Journalists, 1989; Hitchings, 1989).

Throughout these eight weeks, the demonstrations remained nonviolent and peaceful. The tactics the students adopted--marches, demonstrations, sit-ins, petitions, boycotting classes, dialogues and hunger strikes--all reflected the intention of avoiding any social turmoil (Li, Mark \& Li, 1990; Li, 1990).

\section{May Fourth Movement}

Inflation, official corruption, student grievances, and former party leader Hu's death were among the reasons given for the movement. Another important reason for the movement that is often ignored is the spirit of the May Fourth Movement.

The May Fourth Movement took place in 1919, and was named after the date when police in Beijing arrested and beat up scores of student marchers for taking part in a demonstration protesting certain terms of the Treaty of Versailles, under which World War I allies would transfer parts of China formerly under German control to Japan, rather than returning the territories to the Chinese. Like so many student movements in so many times and places, the May Fourth Movement became as much a fight for the right to protest as a struggle against imperialism and corruption (Wasserstrom, 1990).

The meaning of the term "May Fourth" often went beyond just "a synonym for patriotic student activism," Wasserstrom (1990) noted, explaining that the intellectuals and politicians had added more significant meanings to it. To intellectuals, it was associated with free thinking and a search for enlightenment--the concepts of science and democracy. The Chinese Communist Party marked May 4, 1919 as the beginning of the "New Democratic Revolution" that eventually resulted in the new China.

Using the positive myth surrounding the May Fourth traditions, which were defined as patriotic, nationalist, and democratic, Chinese scholars and politicians commemorated 
the May Fourth anniversary every year with debates and criticism of current Chinese politics.

It was not surprising that long before Hu's death, student activists in Beijing and other cities had been planning to use the occasion of the 70th anniversary of the May Fourth Movement to start a new round of demonstrations protesting government corruption and the lack of political reform (Wasserstrom, 1990). Hu's death on April 15 merely provided a reason for the demonstrations to start two weeks ahead of schedule. "Had there been no student movement of April 1989," David Kelly (1990) contended, "the 70th anniversary of the May Fourth Movement would have brought about a natural peak of consciousnessraising. Even without this, intellectuals were becoming aware as never before of both their own and the nation's predicament and of the need to act in concert to deal with it" (p. 26).

When student protesters in the Spring of 1989 appropriated the symbolism of May Fourth and viewed their actions as part of a tradition of patriotic political engagement, the official press tried to present pro-democracy protesters as being influenced by Western ideas, or portrayed the demonstrations as mere "riots" stirred up by "small groups of troublemakers" with anti-government agendas.

The democracy movement in the Spring of 1989 had inherited the May Fourth spirit and carried it forward to new heights ( $\mathrm{Li}, \mathrm{Mark} \& \mathrm{Li}, 1990)$.

\section{Hong Kong's Return to China in 1997}

In 1997 Britain will turn over its last colony, Hong Kong, to the People's Republic of China as a special capitalist region of socialist China. Because of the 1997 factor and Hong Kong's proximity to China, the people of Hong Kong have great concerns about how the 1989 Chinese democracy movement evolved and what it accomplished.

Aware that today's Beijing may be tomorrow's Hong Kong, the people of Hong Kong, from the general public to celebrities, actively involved themselves in the process of 
supporting the Beijing students. Not only did they have a million people demonstrate to denounce the implementation of Martial Law in Beijing, they also donated more than ten million Hong Kong dollars collectively and transported badly needed tents and cash to the students occupying Tiananmen Square (Sixty-four HK Journalists, 1989).

With 1997 approaching, the Hong Kong press watched Beijing's moves with immense apprehension (Chan \& Lee, 1991). However, the objectivity of the reportage suffered when the reporters became participants rather than distant observers. In the Spring of 1989 , witnessing the struggle for a democratic China, the conflicts between being a concerned Chinese and an objective journalist often pushed the Hong Kong journalists into a catch-22 situation. "Self-consciousness, patriotism, and professionalism tangled together" when they covered the students' demonstrations in Beijing. They saluted the demonstrators with "V" signs, dipped in their own wallets for donations, treated students to hot meals, some cigarettes, and even loaned their hotel rooms to student leaders for meetings or for rest (Low, Wang, Chan, Fan, \& Lai, 1989).

\section{Taiwan's Mainland Policies}

After eight years of civil war and 40 years of hostilities, Communist China and Nationalist Taiwan are finally carefully testing the cold water that separates them. In the late 1980s, Deng signaled to Taiwan that his philosophy of "two systems coexisting in one country" could apply not only in Hong Kong after 1997, but also to Taiwan in the future.

Following this gesture, the two governments informally allowed unofficial communications and visits via a third country or region. However, some politicians were very bitter about this 'friendly' gesture taken by Taiwan towards its long term enemy, the government of Communist China.

In the hope of reforming the government in the process of the Chinese modernization process, and because of the growing corruption spreading among high- 
ranking government officials in China, the student demonstrators called for more democracy and freedom of speech while ignoring the government's prohibition of unauthorized demonstrations. Taiwan's right-wing activists jumped on the opportunity to support this 'anti-Communist' movement. After a few speeches to push the government to take a formal stand in support of the Beijing students, Taiwan activists organized materials and supplies for the Beijing students. To their surprise, the Beijing students refused to have anything to do with Taiwan in general (World Journal, May 21, 1989, pp. 2-3). These activists were left to provide moral support and organize Taiwanese students to collect signatures (World Journal, May 22, 1989, p. 5).

However, there wasn't any self-motivated demonstrations or deep concern among the general Taiwan public, like that shown by the Hong Kong people. Thus, it was Taiwan's politicians, rather than its general public, who showed their concern for this event.

The World Joumal did have very comprehensive coverage of the event. However, it was not because of the interest from the Taiwanese public that motivated it to provide such a high volume of coverage, but rather because of its concerned Chinese readers in the United States. These readers included many students and political dissidents from China who could closely relate their own fates to that of the Beijing demonstrators. 


\section{CHAPTER V \\ CONTENT ANALYSIS OF THE DIFFERENCES \\ IN COVERAGE OF THE DEMOCRACY MOVEMENT}

Chinese-language newspapers in North America can be divided into two main categories: those that are fully financed and published by Chinese-Americans or ChineseCanadians and those who partially or fully rely on foreign financial and editorial support. The three dailies in this study, the World Journal, People's Daily, and Sing Tao Jih Pao, belong to the latter. Because of the linkage with their parent news groups in their homelands, these newspapers are usually shaped by two sets of constraints: their homelands and their host countries. By focusing on these three newspapers which shared the same audience--Chinese and Chinese-Americans living in Northern California--and their coverage of a same event--the 1989 pro-democracy movement in China--this study was designed to identify the characteristics of each newspaper as well as the differences among them.

\section{Coverage in the World Journal}

The World Journal was founded in the United States in 1976 by the Taiwan-based United Daily News Group. It was set up "to provide Chinese Americans with news of their homeland and to ensure that Chinese Americans have the information they need to adapt themselves to their new communities" (World Journal Inc., 1990). Today it publishes four North American editions in New York, San Francisco, Los Angeles, and Toronto to serve the East, West, and Central United States as well as Canada, respectively. In addition to these four publishing offices, there are two dozen business offices in between to assure its services to every Chinese-American community.

This study concentrates on the San Francisco edition, which serves Northern 
California, Nevada, Idaho, Oregon, Washington, Alberta, and British Columbia. Like many Chinese-language media in the United States, the World Journal doesn't have an independent circulation index. However, it claimed "of the 350,000 Chinese-Americans living in the area, over 150,000 read the World Journal daily" (World Journal Inc., 1990). More than $60 \%$ of its readers have been living in the United States for five to ten years, while the rest have lived here for less than five years.

Believing that those of Chinese descent had a thirst for news of the people and happenings in their homeland, the World Journal devoted half of its news hole to Chinese news, a quarter to news in America, and the rest to both world news and San Francisco Bay Area news (World Journal Inc., 1990).

Although its parent news group has a full news agency and 18 publications that circulate throughout the world, the operation of the World Journal in North America is centrally managed by its head office established in New York. Seven days a week, the New York office prepares the important news pages and transmits them via satellite for use in all North American World Journal editions (World Journal Inc., 1990). In addition, the entertainment section, including the Sunday magazine, is prepared and transmitted directly from its parent news group in Taiwan. What distinguishes each of the four North American editions are their local news and local advertisements.

Coverage of the Chinese democracy movement. In the Spring of 1989, the World Journal used up to $60 \%$ of its average daily news hole to cover the Chinese pro-democracy movement. The amount of news coverage grew gradually as the event developed and received more and more attention (see Figure 1). During this gradual growth, it was the individual incidents that created one wave of coverage after another. These incidents included the non-official funeral for $\mathrm{Hu}$ attended by 20,000 students and residents in Tiananmen Square on April 22, a 14-hour march joined by tens of thousands to protest the 
negative People's Daily editorial on April 27, the thousands of students and journalists who demonstrated on May 4 to commemorate the May Fourth Movement of 1919 and to demand freedom of the press today, and the announcement of Martial Law on the night of May 20. Each of these incidents set a new peak in the World Joumal 's coverage of the pro-democracy movement.

Of the total coverage, $72 \%$ appeared in the first nine pages of the 60 -page-newspaper. These foremost pages include three pages of Major News, one page of Living, two pages each for Taiwan News and Hong Kong News, and one page for Mainland (China) News.

Figure 1

Percent of News Hole in the World Journal Devoted to the Democracy Movement between April 15, 1989 and June 10, 1989

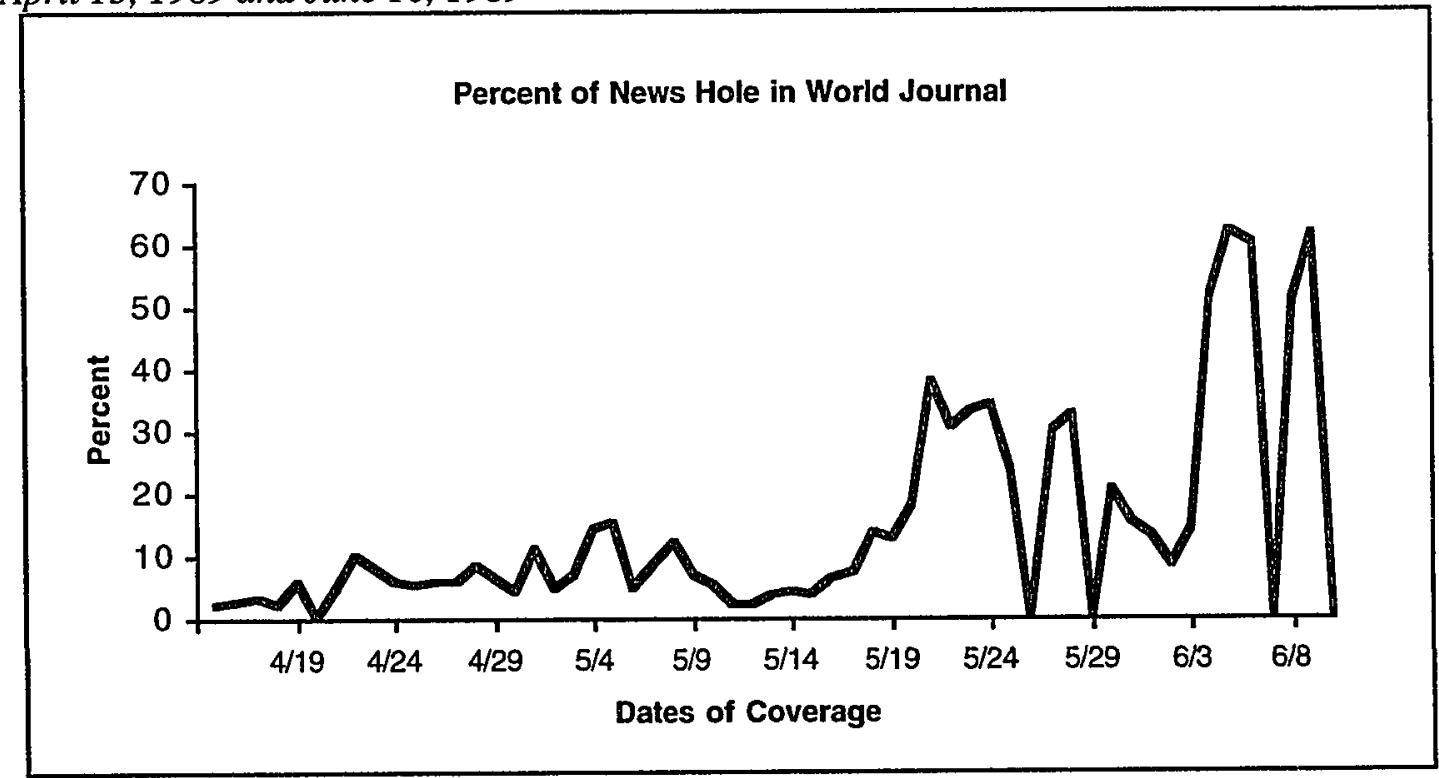

Type of coverage. The World Journal had a great interest in reporting the Chinese student movement not just as a news event, but also for its political interest. It used up to $60 \%$ of its news hole to cover this event, as shown in Figure 1. More than $86 \%$ of this 
coverage was news stories and news pictures that focused on the day-to-day developments of the event, while $10 \%$ was editorials and commentaries.

For instance, two weeks after Hu's death and a series of demonstrations, the World Journal devoted 24 stories to the coverage of the event on May 1, 1989. Twenty-two of the items were news stories and photos. Topics included discussion of the so-called dialogues held between the Beijing government and their hand-picked students, the protest of People's Daily reporters that ensued as the result of the cease of publication of an outspoken newspaper--the World Economic Herald--and waves of scholarly conferences, street demonstrations, and financial support from Hong Kong and the United States as the overseas Chinese responded to the movement. By May 21, five weeks into the movement and less than 24 hours after the martial law announcement, the World Joumal devoted $38 \%$ of its news hole to the movement and increased its coverage to 58 stories. Of these, 53 were news stories and news photographs. They reported the latest actions taking place in Beijing, especially that of the military. Half a million people rallied in Hong Kong and many demonstrated in America to denounce Beijing's martial law. Some Taiwanese officials also considered sending the most needed supplies to the Beijing demonstrators through informal channels.

Although coverage of the day-by-day developments satisfied general readers, the World Journal was interested in exploring the potential political implications of the movement. On April 18, three days after Hu's death and after there had been a few demonstrations to mourn him, the World Journal pointed out that "by mourning $\mathrm{Hu}$, Chinese intellectuals clearly expressed their requests for both economic and political reforms which Hu supported. In contrast, Deng only allowed adoption of Western technologies but not Western ideologies. In order to prolong its dictatorship, Deng's government would never let in any temptations of freedom and democracy"(World 
Journal, April 18, 1989, p. 2). On April 22, when analyzing the six demands of demonstrators, the World Journal commented "though students did not verbally call for ignoring the leadership of the Communist Party and government, their demonstrations themselves were signs of negation towards such leadership"(World Journal , April 22, 1989, p. 2).

Sources of news. The World Journal is part of the Taiwan-based United News Group, which has a worldwide news agency. Relying on its own reporters and its parent .-news group overseas, the World Journal generated $76 \%$ of its news on the event. The rest of the news was from Western news agencies (19\%) and the other from Chinese news groups $(5 \%)$.

Caution should be used when reading these figures. Because of the complicated and fast development of the movement and because of the usual disinformation policy practiced by the Beijing government, it was very hard to maintain accuracy in reporting news on this event. Although American newspapers insisted on not printing any news without more than one source (He \& Zhu, 1994), many Chinese-language newspapers went ahead with information sometimes without clear and reliable sources (Low, Wang, Chan, Fan, \& Lai, 1989). The World Journal had news stories with sources such as "a summary of the Western media" and "according to an unidentified source." Not surprisingly, the World Journal printed rumors at times. On June 6, two days after the Beijing massacre, in two-color and extra-large type, the World Journal claimed "Deng died, General Yang fled, and Li Peng shot" and "Civil war started . . . PLA Army \#38 and \#39 Closed in to Attack \#27 Near Tiananmen Square."

However, the World Journal depended very heavily on AP, UPI, Reuters, and other Western news agencies for photographs of the developments inside China. Its own reporters took most of the pictures taken outside of mainland China. 
Although the World Journal had always designated one-sixth of its second page for daily editorials, many commentaries on other pages were often filled by known scholars from either Taiwan or China. Occasionally, the World Journal reprinted commentaries and analyses that ran in other newspapers or the full speech of some politicians. For example, on June 1 the World Journal had five commentaries: one was an analysis of Bush's China policy by the Christian Science Monitor, two were analyses by a special contributor to the World Journal on the power struggle between Li Peng and his rival Zhao Zhiyang, and the last two were pieces by several mainland scholars located at,Stanford University and the University of California-Berkeley. This illustrates why more than half of the commentaries and editorials in the World Journal were not written by staffers.

During April 15 to June 10, sixteen advertisements were coded for this study because their content directly related to the movement. Of these, $94 \%$ were sponsored by readers and special interest groups in Northern California to express their support for the students after the Martial Law was announced and to condemn the Chinese government after June 4 Massacre occurred.

Table 2

Type of coverage in the World Journal

\begin{tabular}{lllllc}
\hline Sources & $\begin{array}{l}\text { News } \\
(\mathrm{n}=1,137)\end{array}$ & $\begin{array}{l}\text { Features } \\
(\mathrm{n}=43)\end{array}$ & $\begin{array}{l}\text { Editorials } \\
(\mathrm{n}=160)\end{array}$ & $\begin{array}{l}\text { Photo } \\
(\mathrm{n}=220)\end{array}$ & $\begin{array}{l}\text { Ads } \\
(\mathrm{n}=16)\end{array}$ \\
\hline Own staff & $76 \%$ & $47 \%$ & $33 \%$ & $32 \%$ & $6 \%$ \\
Western Agencies & 19 & 12 & 13 & 66 & 0 \\
Others & 5 & 25 & 54 & 2 & 94 \\
\hline
\end{tabular}

Note. "Own staff" refers to source from World Journal and its parent news group overseas. "Western Agencies" include sources from both newspapers and news agencies from the West. "Others" includes sources from other Chinese newspapers and news agencies worldwide as well as individual special contributors. 
Tone of the coverage and sources of news. Overwhelmingly, the World Journal covered the movement in a positive (79\%) and a neutral (19\%) tone. Table 3 indicates that more than $95 \%$ of the news from the World Journal, other Chinese newspapers, and agencies in Hong Kong and Taiwan, and Western agencies were in a neutral to positive tone. In contrast, stories that originated from Xinhua News Agency, the official Communist news agency in China, were primarily negative (83\%).

Table 3

Tone of the Coverage and Sources of News in the World Journal

\begin{tabular}{llllc}
\hline Tone & $\begin{array}{l}\text { Own } \\
\text { Staff } \\
(\mathrm{n}=965)\end{array}$ & $\begin{array}{l}\text { Other } \\
\text { Chinese } \\
(\mathrm{n}=145)\end{array}$ & $\begin{array}{l}\text { Western } \\
\text { Agencies } \\
(\mathrm{n}=348)\end{array}$ & $\begin{array}{l}\text { Xinhua } \\
\text { Agency } \\
(\mathrm{n}=24)\end{array}$ \\
\hline Positive (79\%) & $83 \%$ & $78 \%$ & $74 \%$ & $4 \%$ \\
Neutral (19) & 17 & 20 & 25 & 13 \\
Negative (2) & 0 & 2 & 1 & 83
\end{tabular}

Note. "Other Chinese" includes sources from other Chinese newspapers and agencies in Hong Kong and Taiwan as well as individual special contributors. "Xinhua Agency" includes sources from People's Daily and Xinhua News Agency, the two mouthpieces of the Beijing government.

Purpose of the movement and the sources of news. The study found a very high correlation $(r=.89)$ at the .001 level of significance between news sources and the explanation of the purposes of the movement. Most of the portrayals of the 1989 Chinese student movement from the World Journal, other Chinese newspapers and agencies from Hong Kong and Taiwan, and the Western news agencies were positive. In contrast, most of the pieces that originated from Xinhua News Agency, which is owned and tightly controlled by the Communist government in China, referred to the movement first as "concerns of the nation," then "riots" and later "anti-revolutionary and anti-governmental 
schemes which were organized and manipulated by a few black hands" ( $\mathrm{Li}, 1989)$.

The World Journal printed a few articles from Xinhua News Agency, mainly commentaries, to illustrate how the Beijing government responded to the demonstrators' requests and why waves of demonstrations started. Among those being reprinted in the World Journal were the "April 26 Editorial" that originated in the People's Daily, which defined the movement as "riots," and a full version of the Martial Law Announcement issued by Li Peng on May 20.

Reaction to the movement. The reaction of the Beijing government and the general public in China to the Chinese student movement were measured. Excluding the missing 4 issues out of the 56 issues that were published during this period, $63 \%$ of the stories showed that the government criticized the movement and almost none showed support. However, more than half of the stories (59\%) indicated that the Chinese public supported the students' movement.

Table 4

Reaction to the Movement by China's Government and Residents in the World Journal

\begin{tabular}{lcc}
\hline $\begin{array}{l}\text { Reaction toward } \\
\text { Movement }\end{array}$ & $\begin{array}{c}\text { Beijing Government } \\
(\mathrm{n}=1,597)\end{array}$ & $\begin{array}{c}\text { Chinese Residents } \\
(\mathrm{n}=1,597)\end{array}$ \\
\hline No Mention & $16 \%$ & $27 \%$ \\
Criticism & 63 & 0 \\
Neutral & 21 & 14 \\
Approval & 0 & 59
\end{tabular}

Note. "Neutral" includes two categories: "neither criticism nor support" and "both criticism and support."

Causes of the movement as the event developed. Because of the complexity and the constant development of the movement, this study divided the eight weeks of 
observation into six periods (see Chapter 3). Each period started with a small incident that touched off a big one. First there were waves of demonstrations and other activities that resulted from the public's concern about $\mathrm{Hu}$ and what it felt was the unjustified official judgment of his status after his death. Another wave of demonstrations was ignited by the name-calling editorial of The People's Daily, which referred to the peaceful sit-ins and demonstrations as "riots" and "disturbances."

In every time period, the World Journal gave various explanations as to why each demonstration or other activities took place. As time went by, the dominant reasons given varied. In general, "demands for democracy," "indifference of the government towards the demonstrators" and "repression of the demonstrators by the government" were the three major reasons given by the World Journal throughout its coverage. Although the democratic requests were the causes identified by about $10-20 \%$ of the total stories throughout the six periods, "repression of the movement" was the dominant reason when People's Daily publicly denounced the demonstrations as riots in the second period, when martial law was announced in the fifth period, and when the massacre occurred in the sixth period. In contrast, governmental indifference towards the demonstrations and the demonstrators' requests was the dominant reason given before the imposition of martial law. 
Figure 2

Causes of the Movement over Six Time Periods in the World Journal

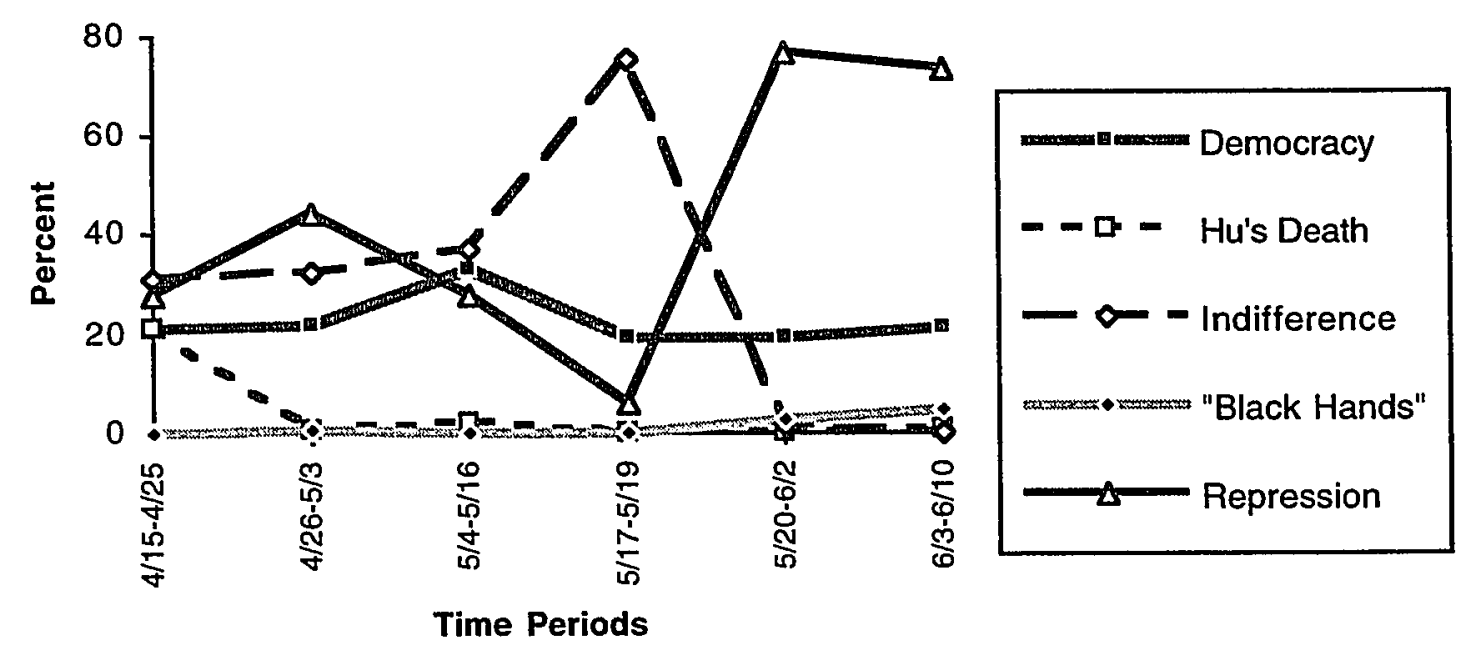

\section{Coverage in People's Daily}

In the People's Republic of China, the People's Daily has been the number one newspaper in terms of serving the government. In addition to being owned by the government like $99 \%$ of the media in China, People's Daily is supervised by a director who sits on the Central Committee of the ruling Communist Party. Editorials in People's Daily have always been interpreted as voicing the official viewpoint of the Communist Party and the Chinese government (Chang, 1989).

The People's Daily was usually overseen by the propaganda unit of the Central Committee of the party, which includes a member of the Politburo standing committee. In 1989 as the students' movement progressed, many journalists, including those from People's Daily, joined the demonstrations and demanded freedom of speech. As a result of some dialogues between the journalists and the propaganda unit headed by Hu Qili, the 
Chinese press tasted a brief breath of freedom in May 1989. Following the announcement of Martial Law in late May, a "crisis propaganda unit" was set up by the hardline Premier Li Peng and it replaced the previous unit. This unit drafted the official stories of the movement for the Xinhua News Agency and it instructed all Chinese media to publish nothing but only the official stories from Xinhua News Agency when covering the demonstrations. After the massacre, detachments from the People's Liberation Army were sent in to guard the compounds at every major media outlet, including the headquarter of People's Daily (Liang et al., 1989).

In short, People's Daily enjoyed the least freedom in reportage among the three newspapers under study. Nevertheless, the Spring of 1989 was an exiting and interesting period for the paper because it was in the middle of the struggle for more freedom of speech and press and it did experience a short period when it had slightly more independence from government controls.

Since the overseas edition of People's Daily was also edited in Beijing, it also was subject to strict organizational control. However, since it is supported by and is a propaganda organ of the CCP, the People's Daily overseas edition was the only Chineselanguage newspaper that could afford to send free subscriptions to Chinese exchange scholars and students; the free subscriptions ended in 1993.

Format. The eight-page overseas edition of People's Daily is published daily Monday through Saturday. It devotes its front page to major domestic and foreign events, its second page to commentaries, profiles, and special articles; its third page to economic news; and its fourth page to politics, law, education, and science. Its fifth page is for reports on Hong Kong, Macao, Taiwan, and typical hometowns of overseas Chinese. Its sixth page is for international news and sports, its seventh page is for literature and arts, and its last page is for excerpts from other newspapers and journals. 
In 1989, when covering the students' demonstrations, $65 \%$ of these stories appeared on the first page of its overseas edition.

Coverage of the Chinese pro-democracy movement. In Spring 1989, most of the student demonstrations took place in Beijing, only miles from the headquarter of People's Daily. In contrast, newspapers overseas were debating how many reporters they could afford to send to Beijing and whether China's government would accredit additional foreign journalists to go to Beijing.

If proximity were the only determining factor, People's Daily would have been the paper which provided the latest and best coverage of the student demonstrations. If the reporters would have had the freedom to cover the big event that many of their readers were interested in reading about or to support the demands for "correcting the governmental corruptions" and "freedom of speech" which were important to Beijing journalists, People's Daily would have given the greatest amount of coverage to the movement. Because of institutional, ideological, and organizational constraints--most of which go beyond the scope of this study-People's Daily never did use more than $30 \%$ of its total news hole to cover the demonstrations.

Figure 3 shows that the first peak of coverage appeared in late April. During this period 10,000 students and residents held an outdoor funeral for Hu after their request to participate in the official funeral was turned down. Also, during this period, students in Beijing started their walkouts in which nearly a million students and Beijing residents marched through layers of police to protest against the negative People's Daily editorial titled: "We must have a clear stand in combating the riots." The second peak was on the eve of the martial law in mid-May. In those few days, when hundreds of hunger strikers were rushed to hospitals, tens of thousands of Beijing residents from all walks of life, including scholars and government leaders, marched to support the students. The open 
struggle between Premier Li Peng and Party Secretary General Zhao Zhiyang created a temporary "power vacuum" that made more coverage, including some prodemocracy coverage possible.

Figure 3

Percent of News Hole in People's Daily Devoted to Coverage of the Movement between April 15 to June 10, 1989

Percent of News Hole in People's Daily

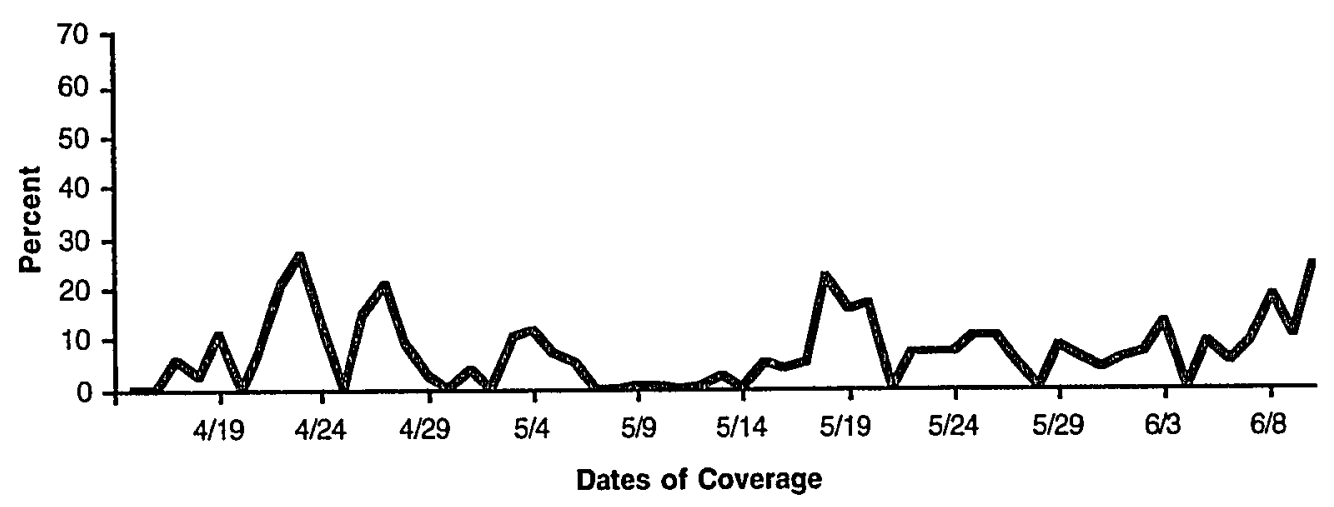

Causes of the Movement in People's Daily. In mid-April, $90 \%$ of the related stories in People's Daily attributed many demonstrations and other activities to an act of "mourning Hu's death." In late April, following its negative editorial calling the demonstrations "disturbances and riots" and during the martial law period in late May and early June, People's Daily claimed the students and demonstrators were manipulated by "a few black hands" behind the scenes. In between these two extremes, for most of May, People's Daily recognized and attributed the demonstrations to the six requests raised by the demonstrators, including "correction of corruption" and "freedom of speech." 
Figure 4

Causes of the Movement over Six Time Periods in People's Daily

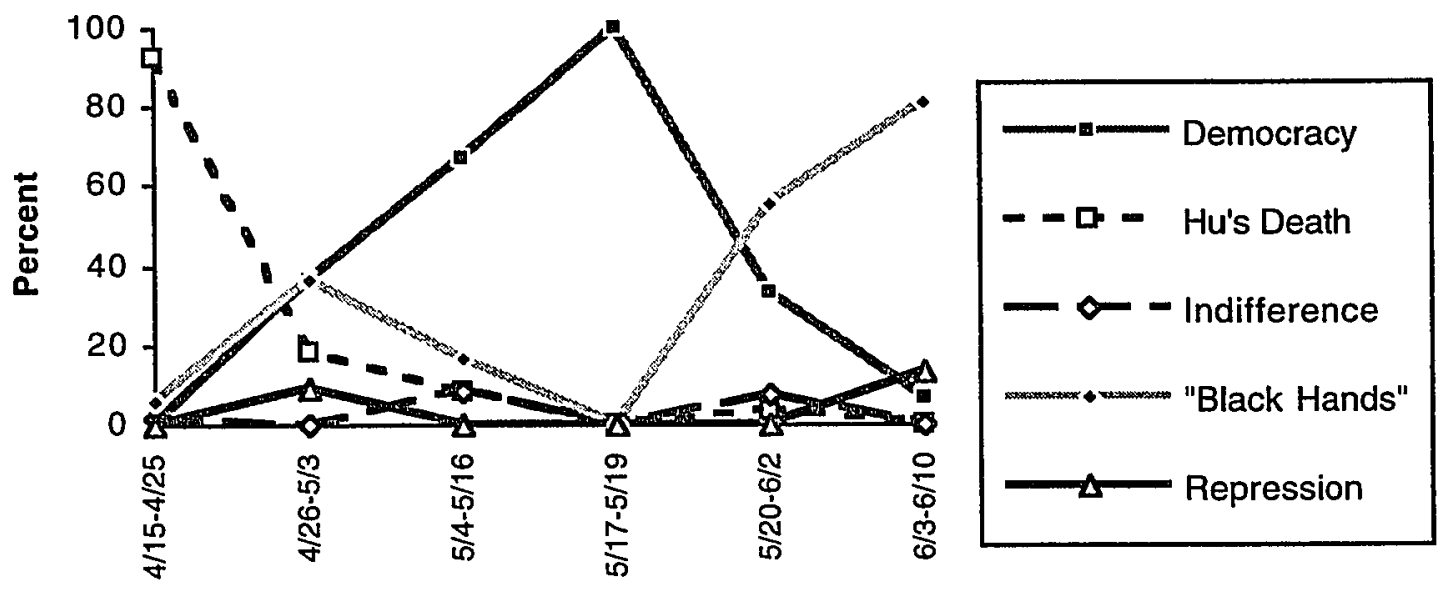

Time Periods

Type of coverage and sources of news. Although People's Daily has more than 600 staff members (Chang, 1989), it relied on Xinhua News Agency for half of its news and $78 \%$ of its commentaries. At least this was the case in reporting the students' movement in the spring of 1989. In this study, the category "commentaries" included the official speeches and announcements in People's Daily that were often published as policies for the Party cadres as well as the local media and the public to study and follow.

Nevertheless, People's Daily photographers took $84 \%$ of the news photos for its coverage of this event. Many of these pictures concerned Hu and his lifelong contributions to the Party rather than the demonstrators or hunger strikers.

Tone of the coverage and sources of news. Given the fact that People's Daily is the mouthpiece and the organ of the Communist Party, it is not surprising that $47 \%$ of all its stories on the students' movement were negative. 
More than half of the stories were either originated by Xinhua News Agency or speeches of governmental officials. Of the Xinhua stories, $53 \%$ were negative, $37 \%$ were neutral, and $10 \%$ were somewhat positive toward the movement. Reporters at People's Daily provided more than one-third of the coverage of which $37 \%$ was negative, $46 \%$ neutral, and $17 \%$ positive. The one story People's Daily selected from Western newspapers for reprint was, of course, negative toward the demonstrations.

Table 5

Tone of the Coverage by Sources of News in People's Daily

\begin{tabular}{llccl}
\hline $\begin{array}{l}\text { Tone of } \\
\text { Coverage }\end{array}$ & $\begin{array}{l}\text { Own } \\
\text { Staff } \\
(\mathrm{n}=59)\end{array}$ & $\begin{array}{l}\text { Other } \\
\text { Chinese } \\
(\mathrm{n}=17)\end{array}$ & $\begin{array}{l}\text { Western } \\
\text { Agencies } \\
(\mathrm{n}=1)\end{array}$ & $\begin{array}{l}\text { Xinhua } \\
\text { Agency } \\
(\mathrm{n}=96)\end{array}$ \\
\hline Positive & $17 \%$ & $47 \%$ & $0 \%$ & $10 \%$ \\
Neutral & 46 & 6 & 0 & 37 \\
Negative & 37 & 47 & 100 & 53
\end{tabular}

Note. "Other Chinese" included sources from other Chinese newspapers as well as individual special contributors. "Xinhua Agency" includes sources from Xinhua News Agency and announcements of government officials.

Purpose of the movement and sources of news. All of the stories that originated from Xinhua News Agency, about half of the total coverage, charged that the demonstrations were held to create social "riots." Meanwhile all stories contributed by reporters from People's Daily, which made up the other half of the stories, recognized that the general democratic requests were the purpose of these demonstrations. This black and white split between these two official mouthpieces when explaining the purposes of the same movement sounds almost impossible. It is beyond the scope of this study to provide an explanation.

Reaction toward the movement. Nearly half of the stories in the People's Daily 
didn't mention what attitude or actions the government took toward the movement, and more than three-quarters didn't mention the general public's response to the movement. Among those stories that did mention the government's and the public's reaction, $31 \%$ stated that the Chinese government criticized the demonstrators and only $2 \%$ claimed the public did the same. In contrast, $11 \%$ of the stories showed the public supported the demonstrators while only $1 \%$ of the stories showed the government's support.

\section{Coverage in Sing Tao Jih Pao.}

Among the three Chinese-language newspapers in this study, Sing Tao Jih Pao was the first to launch its overseas edition in America in 1967, about a decade before the World Journal and two decades before People's Daily. Sing Tao Jih Pao is the biggest rival of the World Journal for Chinese-language readers in the United States.

Headquartered in Hong Kong, Sing Tao Jih Pao continues to focus on Cantonese speaking Chinese who came from Hong Kong and south China. Its headquarters in Hong Kong prepares and edits the major news and news photographs before transmitting them to its nine overseas offices throughout the world where local news and advertisements will be added. In 1989, Sing Tao Jih Pao published six days a week from Monday to Saturday. All six issues usually carried about forty pages evenly split into two sections: News and Entertainment.

The news section included four pages for main news of the world, the United States, China, and Taiwan; four pages for Hong Kong news; two pages for finance and economics; and two for sports. This section also included one page on mainland China and other Asian countries and one each on California and the United States. The entire entertainment section is prepared, edited, and typeset in Hong Kong before it is sent overseas where only local advertisements are added. 
Forty-five percent of Sing Tao 's coverage on the 1989 students' movement was found in the first four pages of its overseas edition.

Coverage of the Chinese democracy movement. In April 1989, Sing Tao Jih Pao did not pay much attention to either Hu's death or the few confrontations between the students and the police in the capital of China. Even when more and more demonstrations and other activities took place in late April through mid May, Sing Tao kept its usual balance of giving no more than $10 \%$ of its news reportage of this event. The announcement of Martial Law in Beijing led to a million people demonstrating in Hong Kong to protest against the Beijing government. This prompted Sing Tao to increase its coverage of the movement to $40 \%$ of its news hole. On June 5 , one day after the massacre, Sing Tao even devoted more than $60 \%$ of its regular news hole to cover this shocking tragedy.

\section{Figure 5}

Percent of News Hole in Sing Tao Jih Pao Devoted to the Coverage of the Democracy Movement between April 15 and June 10, 1989

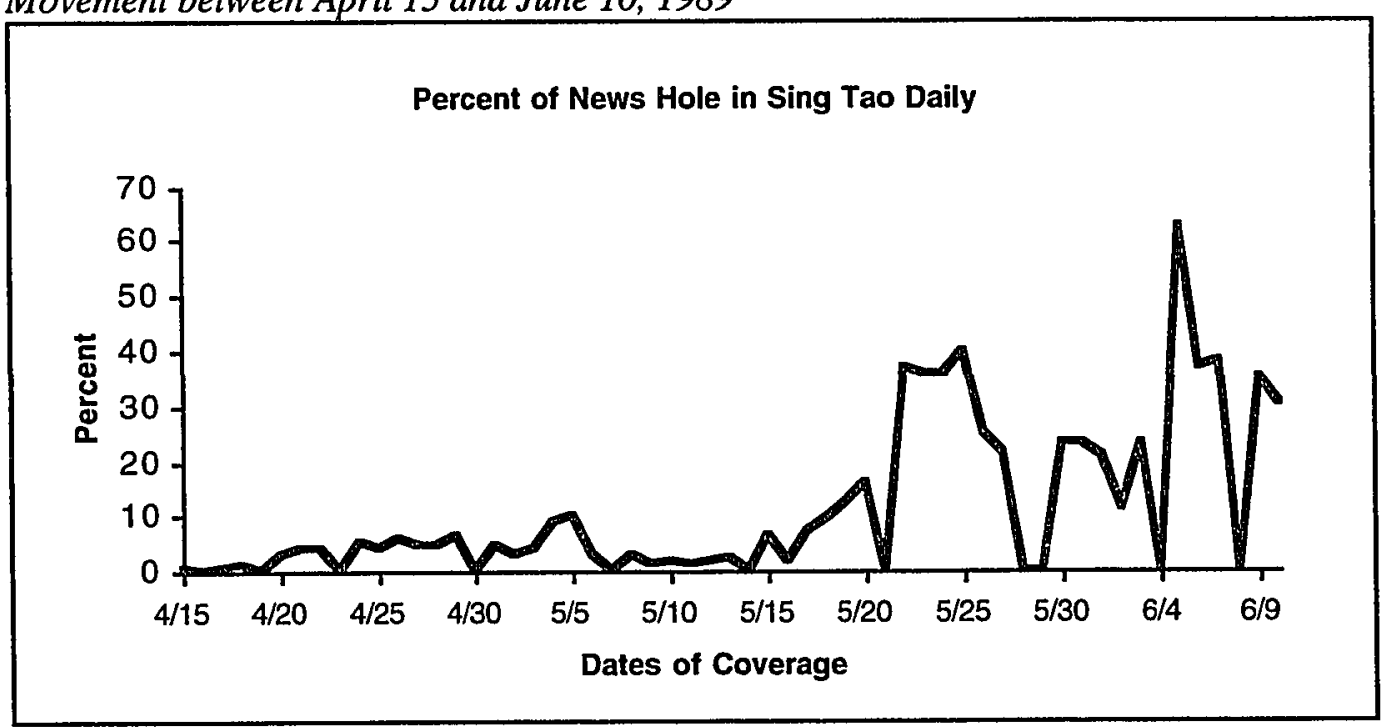


Type of coverage and sources of news. Among the 1,620 cases from Sing Tao Jih Pao, $77 \%$ were news and $13 \%$ were photographs. Only $7 \%$ were editorials.

Sing Tao reporters wrote most of the news and only one-fifth of the stories were from Western newspapers and agencies. Western news agencies also supplied $71 \%$ of the news photos, with Sing Tao's photo journalists providing the rest.

Sing Tao rarely wrote more than one 500-word editorial. More than half of its editorials and commentaries were from special contributors and a quarter were from Beijing's official news agency, the Xinhua News Agency. The kind of scholarly political discussion and analysis frequently published in both the World Journal and People's Daily was not generally found in Sing Tao.

Table 6 clearly shows that Sing Tao had little interest in using other Chinese newspapers or news agencies as sources for its news and feature stories. This could be a result of the fierce competition among Chinese-language newspapers.

Table 6

Type of Coverage by Sources of News in Sing Tao Daily

\begin{tabular}{lllll}
\hline Sources & $\begin{array}{l}\text { News } \\
(n=1,180)\end{array}$ & $\begin{array}{l}\text { Features } \\
(n=45)\end{array}$ & $\begin{array}{l}\text { Editorials } \\
(\mathrm{n}=101)\end{array}$ & $\begin{array}{l}\text { Photo } \\
(\mathrm{n}=200)\end{array}$ \\
\hline Own Staff & $72 \%$ & $36 \%$ & $12 \%$ & $26 \%$ \\
Western Agencies & 20 & 2 & 11 & 71 \\
Other Chinese & 8 & 62 & 77 & 3
\end{tabular}

Note. "Own staff" refers to source from Sing Tao Daily and its parent news group overseas. "Western Agencies" include sources from both newspapers and news agencies from the West. "Other Chinese" includes sources from other Chinese newspapers and news agencies worldwide as well as individual special contributors. 
Tone of the coverage and sources of news. Even more overwhelming than that of the World Joumal, 86\% of Sing Tao's reportage on the movement was positive and only $3 \%$ of it was negative. More than half of the positive stories were reported by its own reporters, while more than half of the negative stories were from Xinhua News Agency or Chinese government.officials.

Except for stories from the Xinhua News Agency, most of the stories Sing Tao selected from other news agencies were either positive or neutral in their reportage of the students' movement.

Table 7

Tone of the Coverage by Sources of News

\begin{tabular}{lllll}
\hline $\begin{array}{l}\text { Tone of } \\
\text { Coverage } \\
(\mathrm{n}=1,510)\end{array}$ & $\begin{array}{l}\text { Sing Tao } \\
\text { Jih Pao } \\
(\mathrm{n}=916)\end{array}$ & $\begin{array}{l}\text { Other } \\
\text { Chinese } \\
(\mathrm{n}=156)\end{array}$ & $\begin{array}{l}\text { Western } \\
\text { Agencies } \\
(\mathrm{n}=387)\end{array}$ & $\begin{array}{l}\text { Xinhua } \\
\text { Agency } \\
(\mathrm{n}=51)\end{array}$ \\
\hline Positive (86\%) & $89 \%$ & $91 \%$ & $87 \%$ & $18 \%$ \\
Neutral (12) & 11 & 8 & 12 & 12 \\
Negative (3) & 1 & 1 & 1 & 49
\end{tabular}

Note. "Other Chinese" included sources from other Chinese newspapers as well as individual special contributors. "Xinhua Agency" includes sources from Xinhua News Agency and announcements of government officials.

Purpose of the movement and the source of news. Similar to that of the World Journal and People's Daily, Sing Tao Jih Pao also had a very high correlation ( $\mathrm{r}=.90)$ between the sources of stories and the explanation of the purpose of the movement at the .001 significance level. Findings showed that all stories reported by reporters of Sing Tao contended that the purpose of the demonstrations was democracy. Stories from Western agencies claimed "freedom of speech" was the main purpose of the demonstrations while 
those from Xinhua News Agency charged that their purpose was to create "riots." Stories that originated from other Chinese newspapers, agencies and individual contributors had a 40-60 split, the former group holding that to "correct existing corruption" was the purpose while the latter attacked the demonstrations aimed to be "anti-governmental."

Reaction to the movement. The reaction of the Beijing government and the general Chinese residents in China to the Chinese student movement were coded and compared. Excluding the missing 2 issues out of the 48 publications, $69 \%$ of the stories showed that the government criticized the movement and almost none showed support. However, more than half of the stories (62\%), indicated that the Chinese residents supported the students' movement.

Table 8

Reaction to the Movement by China's Government and Residents in Sing Tao Daily

\begin{tabular}{lcc}
\hline $\begin{array}{l}\text { Reaction toward } \\
\text { Movement }\end{array}$ & $\begin{array}{c}\text { Beijing Government } \\
(\mathrm{n}=1,620)\end{array}$ & $\begin{array}{c}\text { Chinese Residents } \\
(\mathrm{n}=1,620)\end{array}$ \\
\hline No Mention & $10 \%$ & $27 \%$ \\
Criticism & 69 & 0 \\
Neutral & 20 & 11 \\
Approval & 1 & 62
\end{tabular}

Note. "Neutral" includes two categories: "neither criticism nor support" and "both criticism and support."

Causes of the movement over six time periods. Sing Tao identified four main reasons that resulted in one demonstration after another (see Figure 6).

"The democratic requests ranging from correcting corruption to equal dialogue with the government" had always been a reason given in Sing Tao stories throughout the eight weeks of study. In April it was the explanation for half of the stories, then in May it was 
the explanation for only $10 \%$ of the stories. "Public concern towards Hu and the unfair judgment of him" was the reason for half of the stories only in mid-April, immediately after Hu's death. Starting in May through the eve of Martial Law, "indifference of the government towards the demands raised by the demonstrators" became the most dominant cause for demonstrations, according to Sing Tao's coverage. Once Martial Law was announced on May 20, it was "government's repression of the demonstrators" that caused new waves of demonstrations and other activities.

Sing Tao used very little of its space on scholarly analyses of the movement or China's political situation in general. Neither did it use much space to reprint the Beijing government's accusation of "a few black hands" that manipulated the student movement behind the scenes. Sing Tao did not assume that the Beijing government was being indifferent and repressive towards the student demonstrators at the beginning like the World Journal did. 
Figure 6

Causes of the Movement over Six Time Periods in Sing Tao Jih Pao

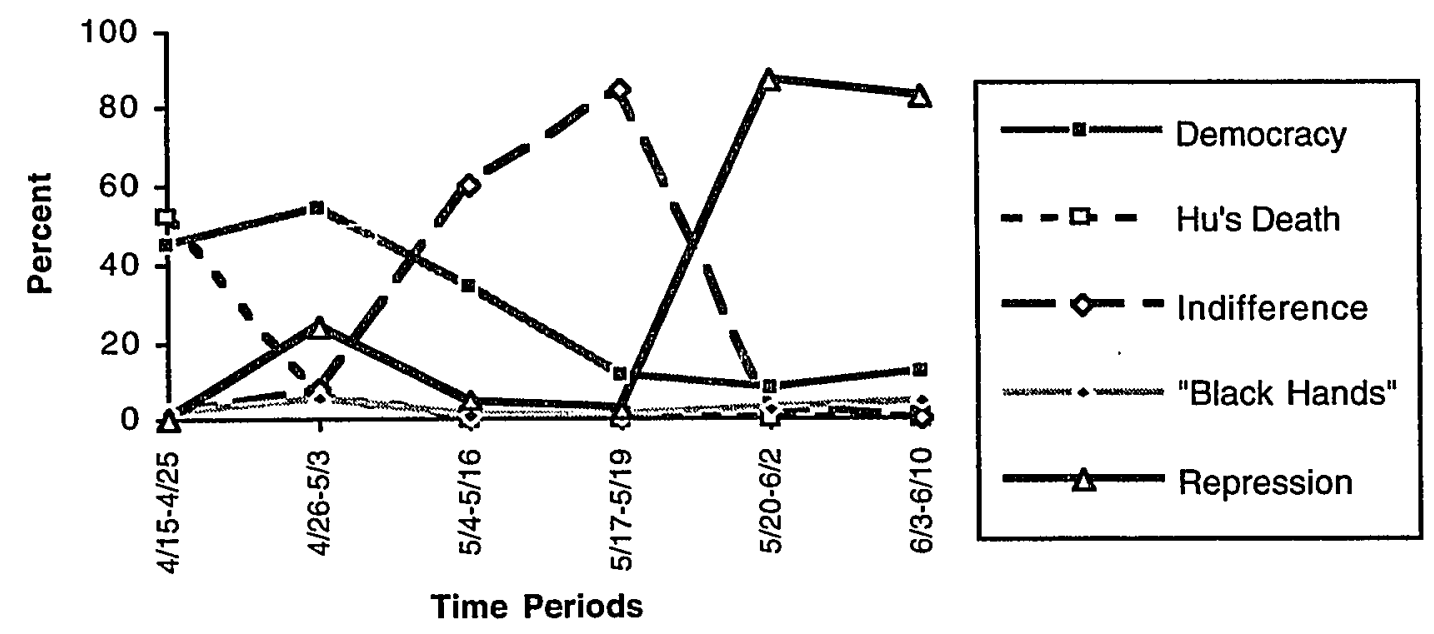

\section{Comparison of the World Journal, People's Daily, and Sing Tao Jih Pao}

In the above discussion of the coverage of each of the three Chinese-language newspapers, there has been some comparisons of their similarities as well as differences. This section will compare the three papers from four new angles.

Cross-comparison on the percentage of news hole during the six time periods. As time went by and the movement developed daily, the amount of coverage in the World Journal, People's Daily, and Sing Tao Jih Pao was very different. While both the World Journal and Sing Tao increased their coverage sharply to include more and more new developments as well as to satisfy the increasingly attentive readers, People's Daily cut down by half its coverage when Martial Law was imposed, only to have the amount of its reportage peak again after the massacre. Most of the coverage in People's Daily after the June 4 massacre was editorials and official speeches.

After the June 4 massacre, the World Journal and Sing Tao scaled back their regular 
news to squeeze in reports and condemning statements that flooded the newspapers. In addition, both added several pages of coverage of the tragic event every day. Figure 7 illustrates how the amount of coverage in each of the newspapers changed during the six time periods.

Figure 7

Comparison of the Amount of Coverage by Percent of News Hole during Six Time Periods

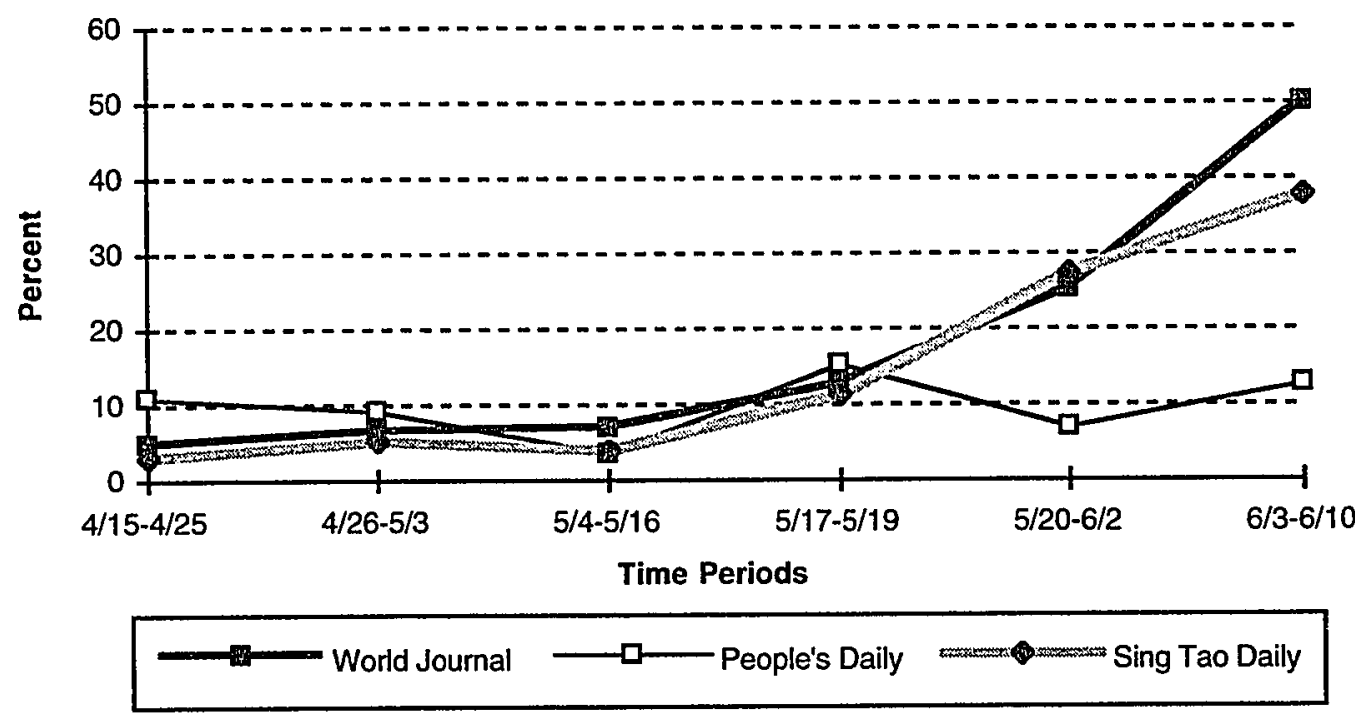

Note. The percentage of coverage was the average for each period.

Cross-comparison of coverage on key players. To determine how each of the three newspapers covered this complex pro-democracy movement, and to determine more about what key players of the event each newspaper chose to cover and in what amount, this study measured 16 categories of potential key players. Although many key players were prominent enough to be recognized by all three newspapers, such as the Chinese students and government, categories such as the non-Communist associations in China hardly caught the attention of any of the papers. 
However, the amount of coverage on the same key player in these three newspapers varied significantly. When the other two newspapers devoted an equal amount of coverage to both the students and the government, People's Daily devoted three times more coverage to the government than to the students. This indicated the tight official control under which People's Daily was operating. Therefore, it was not surprising that People's Daily had more coverage on the People's Liberation Army (PLA) and on responses from Communist countries, while it had almost none on the Taiwanese people or the government of Taiwan (see Figure 8).

Figure 8

Comparison of Coverage on Key Players by the World Journal, People's Daily and Sing Tao Daily between April 15 and June 10, 1989

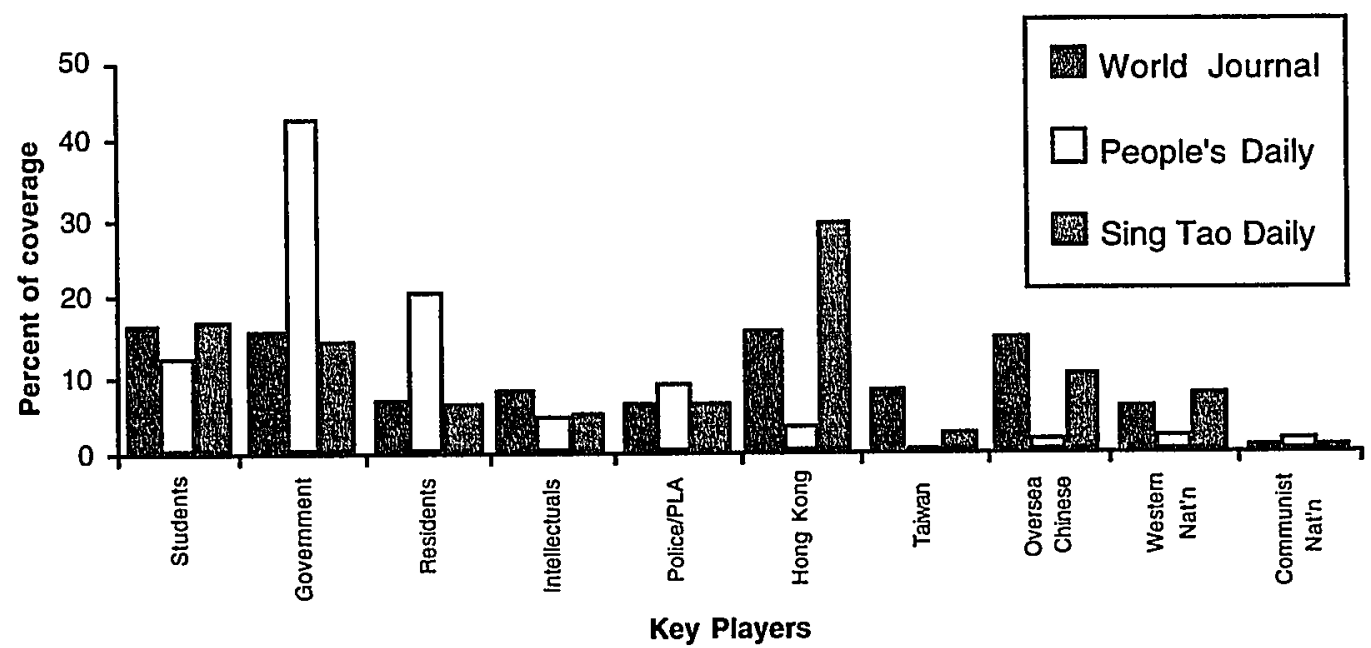

Contrast in the tone of coverage. In addition to the amount of coverage, the tone of coverage on the democracy movement in each newspaper was also very different.

Both the World Journal and Sing Tao Daily consistently provided a very positive image when they covered the democracy movement. Every day during the spring of 1989 , they published pages of stories on the democracy movement. Of these, $80 \%$ were positive 
and less than 5\% were negative (see Figure 9). This obvious tendency of support indicated the Chinese media's involvement in, rather than being an objective observer of, the movement.

In contrast to the World Journal and Sing Tao Daily, $47 \%$ of the coverage of the movement in People's Daily was negative. Although this was not surprising given the very tight organizational and ideological controls that People's Daily was operating under, almost all of the $16 \%$ of its positive coverage was published during the brave breakthrough for a breath of freedom in mid-May, 1989 (also see Figure 4). The government's crackdown was 30 th before and after this short period of freedom, which began with the April 26 Editorial in People's Daily, and was followed by Martial Law that began on May 20 , the June 4 Massacre, and a series of arrests.

The $36 \%$ of neutral coverage of the democracy movement should not be read simply as professional objectivity but rather as a collective subtle resistance against the tight controls of the government. Such examples could be found throughout the coverage of the movement, especially after Martial Law began on May 20. On the front page of the May 22 People's Daily, directly under Primer Li Peng's announcement of Martial Law and right next to the Beijing Mayor's announcement of Emergency Ordinance, there was a feature titled "Days of Martial Law in Beijing." It calmly and neutraliy described the fact that the demonstrators continued their sit-in at Tiananmen Square and that thousands of Beijing residents voluntarily blocked all main streets leading toward the Square to prevent the military's entrance into the city. Despite growing pressure and control from the government, a similar feature reappeared again and again on the front page of People's Daily after Martial Law had been imposed. 
Figure 9

Contrasting Tone in the Coverage of the Democracy Movement by the World Journal, People's Daily, and Sing Tao Daily.

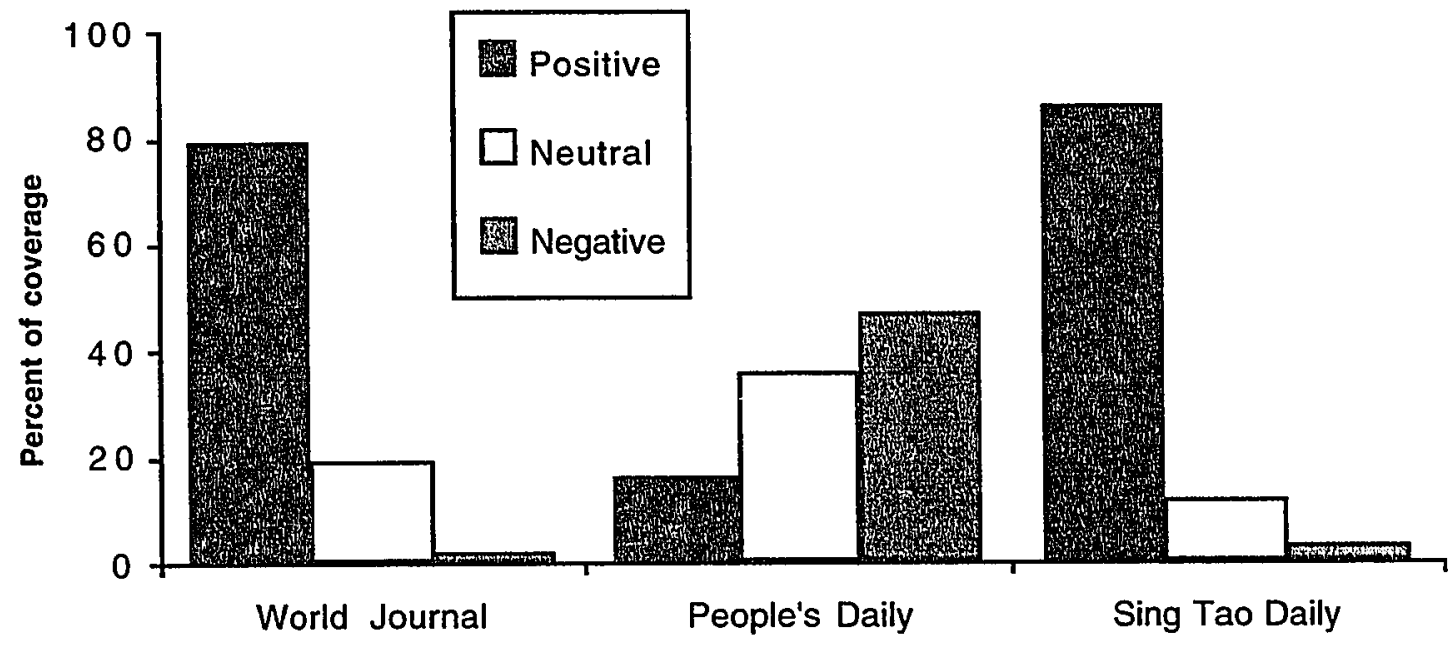

Overall comparisons of the coverage. Earlier in this chapter, many aspects of the coverage were discussed within the context of each newspaper. Table 9 provides an overall look at the differences and similarities among the World Journal, People's Daily, and Sing Tao Daily in their coverage of the 1989 Chinese democracy movement. Scheffé a posteriori contrast tests within the framework of an one-way analysis of variance were conducted for each of the 12 variables in Table 9. 
Table 9

Comparisons of Means for Coverage of the Chinese Democracy Movement in 1989 by the World Journal, People's Daily, and Sing Tao Daily

\begin{tabular}{|c|c|c|c|c|c|}
\hline $\begin{array}{l}\text { Aspects of } \\
\text { Coverage }\end{array}$ & $\begin{array}{c}\text { World Journala } \\
(\mathrm{n}=1,597)\end{array}$ & $\begin{array}{c}\text { People's Dailyb } \\
(\mathrm{n}=304)\end{array}$ & $\begin{array}{c}\text { Sing Tao Dailyc } \\
(n=1,620)\end{array}$ & F & $\begin{array}{l}\text { Scheffe } \\
p<.05\end{array}$ \\
\hline Tone & 1.17 & 1.50 & 1.15 & $33.52 * * *$ & $a b, b c$ \\
\hline News Source & 1.78 & 2.60 & 1.81 & $55.13 * * *$ & $a b, b c$ \\
\hline $\begin{array}{l}\text { Causes of } \\
\text { Movement }\end{array}$ & 2.26 & 1.55 & 2.39 & $26.78 * * *$ & $a b, b c$ \\
\hline $\begin{array}{l}\text { Purpose of } \\
\text { Movement }\end{array}$ & 1.78 & $2.60^{-}$ & 1.81 & $55.13 * * *$ & $a b, b c$ \\
\hline Govt. Reaction & 1.17 & .85 & 1.21 & $24.60 * * *$ & $a b, b c$ \\
\hline $\begin{array}{l}\text { Residents' } \\
\text { Reaction }\end{array}$ & 2.70 & .74 & 2.76 & $185.46^{* * *}$ & $a b, b c$ \\
\hline Style & 1.71 & 1.65 & 1.67 & .53 & n.s. \\
\hline Layout & 1.39 & 1.26 & 1.32 & 1.79 & n.s. \\
\hline $\begin{array}{l}\text { Location of } \\
\text { the Event }\end{array}$ & 2.41 & 1.32 & 2.62 & $93.87 * * *$ & $a b, a c, b c$ \\
\hline Story Size & 179.13 & 178.38 & 138.43 & $18.36 * * *$ & $\mathrm{ac}, \mathrm{bc}$ \\
\hline $\begin{array}{l}\text { Coverage of } \\
\text { Students }\end{array}$ & 16.40 & 12.17 & 17.13 & $3.21^{*}$ & bc \\
\hline $\begin{array}{l}\text { Coverage of } \\
\text { Government }\end{array}$ & 15.58 & 42.86 & 14.20 & $106.89 * * *$ & $a b, b c$ \\
\hline
\end{tabular}

The findings also indicated that both the World Journal and Sing Tao Daily differed significantly from People's Daily in their explanation of the causes and purposes of the movement. However, all three newspapers used a similar style and layout in covering the 
movement. Although the World Journal and People's Daily seemed to utilize their editorials more often than Sing Tao Daily, they all shared a similar proportion of news, features, editorials, and news photos in their coverage of the democracy movement. 


\section{CHAPTER VI \\ CONCLUSION}

This thesis examined the coverage of three Chinese-language newspapers in the United States through an eight-week content analysis of their coverage of the Chinese democracy movement in the spring of 1989. The dailies studied were the World Journal from Taiwan, People's Daily from China, and Sing Tao Jih Pao from Hong Kong.

Because of the historical and geographical separation, political differences and subtle cultural distinctions, these three regions, as well as their press, tend to view events differently. This research looked at whether newspapers from these regions would tend to conform after they "migrated" to the United States and had to compete for the overseas Chinese audience. Findings in this study indicated that the political differences they inherited from their homelands were reflected in their coverage of the Chinese democracy movement in 1989. Although they might have been competing for the same audience, Chinese and Chinese Americans, it was the agenda back home that shaped the coverage in these American editions. For these newspapers, it was a case of same owner, same ideology. In addition, these three newspapers depended on their parent news groups back home for financial support and much of their news.

These American editions of three Chinese-language newspapers virtually carried on their representation of the Chinese press in China, Taiwan, and Hong Kong in their coverage of the Chinese pro-democracy movement. People's Daily was controlled by the Chinese government that the demonstrators were protesting against. It was natural that a pro-government agenda would be adopted by People's Daily. This was also reflected by the distribution of coverage. People's Daily had three times more coverage on the 
government than on the students who initiated the movement and carried it on as the prominent key players. Meanwhile the other two newspapers, the World Journal and Sing Tao Jih Pao, gave an equal amount of coverage to both the students and government. The government's agenda was also reflected in the tone of coverage. Whenever the demonstrations were mentioned, half of the time People's Daily referred to them in a negative tone, while the other two showed consistent support for the demonstrations.

In contrast, Sing Tao Jih Pao from Hong Kong was a more market-oriented newspaper that depended on its understanding of the public's interest. For most Hong Kong people, the 1997 factor was a big concern. They watched Beijing's every move carefully as it would directly influence their fate after Hong Kong returns to China in 1997. The democracy movement in China addressed the general concern of basic human rights, which included freedom of speech and the press. To the publishers' surprise, news about students demonstrations and Beijing government's responses became the hottest topic. Hong Kong newspapers thus started to send more reporters to China's capital and allowed those reporters already in Beijing to stay longer (Sixty-four Hong Kong Journalists, 1989). The quantity of coverage on the Chinese democracy movement grew even faster when the public's general concern escalated to collective support for the Beijing students. All of this illustrated why Sing Tao Jih Pao had the lowest amount of coverage at the beginning, yet had the highest at the end. It also helps to explain why a majority (86\%) of the coverage in Sing Tao Jih Pao referred to the movement in a positive tone.

The World Journal was a part of the United News Group in Taiwan. Although it was an independent private news agency, its owner is a member of the central committee of Taiwan's ruling party. Because of this link with the government and because of Taiwan's historical interest in monitoring every move of Communist China, the World Journal carried out this agenda by running more editorials and commentaries. 


\section{Summary of Findings}

This thesis compared the news coverage of the 1989 Chinese pro-democracy movement in the North American editions of three foreign-linked Chinese-language newspapers: People's Daily from China, the World Journal from Taiwan, and Sing Tao Jih Pao from Hong Kong through a quantitative content analysis. The analysis measured each of the 3,521 news items published by these daily newspapers between April 15 and June 10,1989 with 12 coding categories (see Chapter 3 ).

Major findings are: (1) both Sing Tao Daily and the World Journal increased their coverage sharply as the movement developed while the amount of People's Daily coverage fluctuated along with the oscillation in the tightness of government control; (2) both Sing Tao Daily and the World Journal consistently covered the movement in a very positive tone while half of People's Daily's coverage of the movement was negative; (3) both Sing Tao Daily and the World Joumal relied heavily on its own staff and Western news agencies while $78 \%$ of People's Daily coverage of the movement came from Xinhua News Agency and almost none from Western news agencies; (4) explanations given as causes of the movement as well as the emphasis given to different key players by the three newspapers varied significantly.

\section{Contributions to the Literature}

This research was a quantitative content analysis of three foreign-linked Chineselanguage newspapers in the United States that explained how political ideologies influence media coverage. The findings show that these papers carried over the different ideological influences from their homelands, which contributed to the differences in their coverage of the same event. Although the differences are apparent in the amount and the tone of coverage, as well as the emphasis given to various key players in the event, technical aspects of the reportage, including the style and the layout of stories, tend to be similar. 
These findings indicate that those Chinese-language newspapers having an organizational or financial linkage with their homeland parent news group follow the ideological footprints of their overseas parent news groups.

This thesis contributes to the literature of the 1989 Chinese democracy movement since it is the first study on the media coverage of the Chinese-language press in the United States. Previous studies on media coverage of the movement have been focused on either the Western mainstream media or the Chinese media inside China. This research not only explored how three very different Chinese-language newspapers in the United States covered the event, but also compared the differences among these three newspapers. It was from these newspapers that millions of Chinese and Chinese-Americans learned about the movement. In turn, it was through these newspapers that they expressed their support for the demonstrators. Therefore, studies of these newspapers contributed to the scholarly understanding of the information role played by the Chinese-language press in the United States during the Chinese democracy movement in the spring of 1989.

\section{Limitations of the Study}

Data collection for this study was to include all the coverage of the Chinese prodemocracy movement in the three targeted daily newspapers from April 15 to June 10, 1989. Although 6 issues out of the 154 total publications were missing, the collection of 3,521 stories during these 57 days was more than sufficient for the quantitative content analysis conducted for this study.

However, all data were collected from one single news event in the spring of 1989. To study one newspaper's coverage of several news events in different time periods may generate a fuller description of its coverage patterns and philosophies.

This study explored the correlations between ideologies and coverage, rather than other influencing factors which include organizational and individual controls. Interviews 
with the journalists and editors in the three targeted newspapers were not conducted. Such interviews could have provided insight which would help to explain why and how they covered the movement the way they did.

\section{Directions for Further Research}

Little research has been done on the Chinese-lauguage press in the United States. Today, there isn't any up-to-date directory that lists the more than 100 Chinese-language newspapers and magazines. The last such publication was published in the $1950 \mathrm{~s}$.

Although the World Journal and Sing Tao Daily are the two dominant dailies on the coasts, it takes a week for them to get to the Chinese communities in the Midwest. Thus, many smaller Chinese-language newspapers such as the Chinese American Post in Denver and The Newcomer News in Houston fill in the gap to provide these communities with local news. However, there are often partisan newspapers in each area claiming their links with either the Nationalists in Taiwan or the Communists in China.

Therefore, studies need to be done on both the content and factors that influence Chinese-language newspapers. Suggested research questions are as follows: What is the organizational structure of Chinese-language newspapers and what are the social and political environments within which they operate? What kind of professional skills and training do their staff have? What are the roles and functions of the Chinese-language press in the Chinese-American communities and in the United States?

Although many books and articles have been written on the Chinese democracy movement in 1989 , most of them are testimonies and chronological recordings of the event. Despite the few scholarly studies of this event reviewed in Chapter 2, many more topics concerning the media's role in the movement such as the following should be explored further: How did the Chinese government orchestrate and escalate its repression against the demonstrators in the form of a mass media campaign after June 4, 1989 ? 


\section{REFERENCES}

Altschull, J. Herbert (1984). Agents of power: The role of the news media in human affairs. New York: Longman.

Birt, J. \& Jay, P. (1975, September 3). Why television news is in danger of becoming an anti-social force. The Times.

Budd, Richard W., Thorp, Robert K., \& Donohew, Lewis (1967). Content analysis of communications. New York: The MacMillan Company.

Chan, Joseph M. \& Lee, Chin-Chuan (1991). Mass media and political transition: The Hong Kong press in China's orbit. New York: The Guilford Press.

Chang, Man (1969). The People's Daily and the Red Flag magazine during the cultural revolution. Hong Kong: Union Research Institute.

Chang, Kuo-hsing (1968). A survey of the Chinese language daily press. Hong Kong: Asian Programme International Press Institute.

Chang, Kuo-sin (1982). Hong Kong. In John A. Lent (Ed.), Newspapers in Asia: Contemporary trends and problems (pp. 78-94). Hong Kong: Heinemann Asia.

Chang, Tsan-Kuo (1983, August). The Chinese press in the United States: A linkage to the past. Paper presented at the annual meeting of the Association for Education in Journalism and Mass Communication, Corvallis, OR.

Chang, Won-Ho (1989). Mass media in China: The history and the future. Ames: Iowa State University Press.

Chen, Zhanghong (1991). Journalism reform in China: A comparative study of the press performance during the 1989 Tiananmen student movement (Doctoral dissertation, Oklahoma State University, Stillwater, OK, 1990). Dissertation Abstracts International, 52, 328A.

Chibnall, Steve (1977). Law-and-order news: An analysis of crime reporting in the British press. London: Tavistock Publications Ltd.

Chu, James C. Y. (1982). Republic of China (Taiwan). In John A. Lent (Ed.), Newspapers in Asia: Contemporary trends and problems (pp. 54-77). Hong Kong: Heinemann Asia.

Faison, Seth (1990). The changing role of the Chinese media. In Tony Saich (Ed.), The Chinese people's movement: Perspectives on Spring 1989 (pp. 145-163). Armonk, NY: M. E. Sharpe. 
Gans, Herbert J. (1979). Deciding what's news: A study of CBS Evening News, NBC Nightly News, Newsweek, and Time. New York: Pantheon Books.

Golding, Peter (1974). The mass media. London: Longman.

Glasgow University Media Group (1976). More bad news. London: Routledge \& Kegan Paul.

Gouldner, Alvin W. (1976). The dialectic of ideology and technology. London: MacMillan.

Hachten, William A. (1981). The world news prism: Changing media, clashing ideologies. Ames: Iowa State University Press.

Hall, Stuart (1981). A world at one with itself. In Cohen, Stanley \& Young, Jock (Eds.), The manufacture of news: Social problems, deviance and the mass media (pp. 147-156). Beverly Hills: Sage.

Harris, Paul (1978). Hong Kong: A study in bureaucratic politics. Hong Kong: Heinemann Asia.

He, Zhou (1992). The role of the Chinese national news media and the Voice of America in the 1989 Chinese prodemocracy movement (Doctoral dissertation, Indiana University, Bloomington, IN, 1991). Dissertation Abstracts International, 53, 1711A.

He, Zhou (1993, July). Freedom of the press in China: Its past, present and future. Paper presented at the conference on Research and Education in Chinese Mass Communication, Taipei, Taiwan.

He, Zhou (1994). Personal communication, August 5, 1994, San Jose, CA.

He, Zhou \& Zhu, Jianhua (1994, February). The "Voice of America" and China: Zeroing in on Tiananmen Square. Journalism Monographs, 143.

Hitchings, Thomas E. (Ed.). (1989). Facts on file: World news digest with index (Serial No. 183680). New York: Facts On File.

Houn, Franklin W. (1956). To change a nation: Propaganda and indoctrination in Communist China. New York: Crowell-Collier.

$\mathrm{Hu}$, Yuan-yuan (1973). Chinese newspaper coverage of Communist China's admission to the United Nations. Unpublished master's thesis, San Jose State University, San Jose, CA. 
Huffman, Suzanne, Yang, Tai-en, Yan, Liqun, \& Sanders, Keith P. (1990, August). "Genie out of the Bottle": Three U. S. networks report Tiananmen Square. Paper presented at the annual convention of the Association for Education in Journalism and Mass Communications, Minneapolis, MN.

Kelly, David (1990). Chinese intellectuals in the 1989 democracy movement. In George Hicks (Ed.), The broken mirror: China after Tiananmen (pp. 24-51). Chicago, IL: St James Press.

King, A. Y. (1975). Administrative absorption of politics in Hong Kong: Emphasis on the grass roots level. Asian Survey, 15, pp. 422-439.

Krippendorf, Klaus (1980). Content analysis: An introduction to its methodology. Beverly Hills: Sage.

Lai, H. Mark (1987). The Chinese-American press. In Sally M. Miller (Ed.), The ethnic press in the United States: A historical analysis and handbook (pp. 27-43). New York: Greenwood Press.

Lam, S. F. \& Tam, V. (1990). 1997: Hong Kong in transition. Minneapolis: Hong Kong China Observers.

Landsberger, Stefan R. (1990). Chronology of the 1989 student demonstrations. In Tony Saich (Ed.), The Chinese people's movement: Perspectives on Spring 1989 (pp. 164-189). Armonk, NY: M. E. Sharpe.

Lee, Chin-Chuan (1993, April). Sparking a fire: The press and the ferment of democratic change in Taiwan. Journalism Monographs, 138.

Lendvai, Paul (1983). What is newsworthy--and what is not--in the Communist world? In John Martin and Anju Grover Chaudhary (Eds.), Comparative mass media systems (pp. 67-83). New York: Longman.

Lent, John A. (1982). Newspapers in Asia: Contemporary trends and problems. Hong Kong: Heinemann Asia.

Liang, Mei-Fun, Tam, Wei-Yi, Liu, You-Shiao, Chan, Tin-Kiong, \& Ma, Miou-Wua (1989). Party newspapers do a complete turn about. In Sixty-four Hong Kong Journalists, People will never forget: A true record of 1989 democracy movement (pp. 322-327). Hong Kong: Hong Kong Journalists' Association.

Li, Jinkun (1989). 1989: Retrospection and reflection after turmoil. Tianjin, China: Tianjin Publishing House.

Li, Lu (1990). Moving the mountain: My life in China from the Cultural Revolution to Tiananmen Square. London: MacMillan. 
Li, Peter, Mark, Steven, \& Li, Marjorie H. (1990). Culture and politics in China: An anatomy of Tiananmen Square. London: Transaction Publishers.

Liu, Alan P. L. (1982). People's Republic of China. In John A. Lent (Ed.), Newspapers in Asia: Contemporary trends and problems (pp. 31-53). Hong Kong: Heinemann Asia.

Liu, Alan P. L. (1986). How China is ruled. New Jersey: Prentice-Hill, Inc.

Low, Wing-Hong, Wang, Han-Gwen, Chan, Tin-Kiong, Fan, Chiou-Wan, \& Lai, Pui-Yi (1989). Dark spots in the glory of Hong Kong journalism. In Sixty-four Hong Kong Journalists, People will never forget: A true record of 1989 Democracy Movement (pp. 330-338). Hong Kong: Hong Kong Journalists' Association.

MacFarquar, Roderick (1973, January). A visit to the Chinese press. The China Quarterly, 53, 145-152.

Martin, John L. \& Chaudhary, Anju G. (1983). Comparative mass media systems. New York: Longman.

Martin, John L. \& Hiebert, Ray E. (1990). Current issues in international communication. New York: Longman.

Merrill John C. (1990). Global elite: A newspaper community of reason. Gannett Center Journal, 4, 93-101.

Miller, Sally M. (Ed.). (1987). The ethnic press in the United States: A historical analysis and handbook. New York: Greenwood Press.

Morrison, Donald (Ed.). (1989). Massacre in Beijing: China's struggle for democracy. New York: Time Inc.

Nasser, Munir K. (1983). News values versus ideology: A Third World perspective. In John Martin and Anju G. Chaudhary (Eds.), Comparative mass media systems (pp. 44-66). New York: Longman.

Public Opinion Research Institute of the People's University (1989). A nationwide survey of journalists on their attitudes toward journalism reform. In Chongshan Cheng and Xiuling Er (Eds.), An In-depth Examination of Communication Effects in China. Shengyang, China.

Republic of China: Yearbook. (1989). Taipei, Taiwan: Kwang Hwa Publishing Company.

Rivers, William L., Schramm, Wilbur L., \& Christians, Clifford G. (1980). Responsibility in Mass Communication (3rd ed.). New York: Harper \& Row.

Seymour-Ure, Colin (1974). The political impact of mass media. Beverly Hills: Sage. 
Simmie, Scott \& Nixon, Bob (1989). Tiananmen Square: An eyewitness account of the Chinese people's passionate quest for democracy. Seattle: University of Washington Press.

Sixty-four Hong Kong Journalists (1989). People will never forget: A true record of 1989 democracy movement. Hong Kong: Hong Kong Journalists' Association.

Shoemaker, Pamela J. \& Reese, Stephen D. (1991). Mediating the message. New York: Longman.

Smith, Anthony (1973). The shadow in the cave. London: Quartet.

Tuchman, Gaye (1978). Making news: A study in the construction of reality. New York: The Free Press.

Turow, Joseph (1992). Media systems in society. New York: Longman.

Yi, Mu \& Thompson, Mark V. (1989). Crisis at Tiananmen. San Francisco: China Books and Periodicals.

Yu, Jinglu (1988, Summer). The abortive 1956 reform of Chinese journalism. Journalism Quarterly, 65(2), 328-334.

Yu, Yang-Chou \& Riffe, Daniel (1989, Winter). Chiang and Mao in U. S. news magazines. Journalism Quarterly, 66(4), 913-919.

Wasserstrom, Jeffrey N. (1990). Student protests and Chinese tradition. In Tony Saich (Ed.), The Chinese people's movement: Perspectives on Spring 1989 (pp. 3-24). Armonk, NY: M. E. Sharpe.

Wang, Shujen (1991). Factors influencing cross-national news treatment of a critical national event: A comparative study of six countries' media coverage of the 1989 Chinese student demonstrations (Doctoral dissertation, University of Maryland, 1991). Dissertation Abstracts International, 52, 1930A.

Wimmer, Roger D. \& Dominick, Joseph R. (1991). Mass media research: An introduction. Belmont, CA: Wadsworth.

Zhang, Jianmin (1990, September). A critical analysis of news coverage: A comparison of news coverage of the Beijing student movement in the People's Daily and the New York Times. Unpublished master's thesis, Virginia Commonwealth University, Richmond, VA.

Zhang, Kangcong (1991). A content analysis of major U. S. newspapers' coverage of the 1989 Tiananmen Square massacre. Unpublished master's thesis, University of South Carolina, Columbia. 
Zhang, Zhinian (1990, December). Mass media reform movement in China. Unpublished master's thesis, University of Missouri-Columbia.

Zhu, Jian-Hua (1991). Information availability, source credibility, and audience sophistication: Factors conditioning the effects of Communist propaganda in China (Doctoral dissertation, Indiana University, Bloomington, IN, 1990). Dissertation Abstracts International, 51, 3550A.

Zhu, Jian-Hua \& He, Zhou (1990, May). Knowledge of and attitude toward the June 4th Event: A survey of Chinese students in the United States. Unpublished paper submitted to the Indiana Center for Global Change and World Peace, Bloomington, IN. 